University of Nebraska - Lincoln

DigitalCommons@University of Nebraska - Lincoln

Estimation of Groundwater and Nutrient Fluxes to the Neuse River Estuary, North Carolina

Timothy B. Spruill

U.S. Geological Survey

John F. Bratton

U.S. Geological Survey

Follow this and additional works at: https://digitalcommons.unl.edu/usgsstaffpub

Part of the Earth Sciences Commons

Spruill, Timothy B. and Bratton, John F., "Estimation of Groundwater and Nutrient Fluxes to the Neuse River Estuary, North Carolina" (2008). USGS Staff -- Published Research. 288.

https://digitalcommons.unl.edu/usgsstaffpub/288

This Article is brought to you for free and open access by the US Geological Survey at DigitalCommons@University of Nebraska - Lincoln. It has been accepted for inclusion in USGS Staff -- Published Research by an authorized administrator of DigitalCommons@University of Nebraska - Lincoln. 


\title{
Estimation of Groundwater and Nutrient Fluxes to the Neuse River Estuary, North Carolina
}

\author{
Timothy B. Spruill • John F. Bratton
}

Received: 27 March 2007 /Revised: 1 November 2007 / Accepted: 8 February 2008 / Published online: 20 March 2008

(C) Coastal and Estuarine Research Federation 2008

\begin{abstract}
A study was conducted between April 2004 and September 2005 to estimate groundwater and nutrient discharge to the Neuse River estuary in North Carolina. The largest groundwater fluxes were observed to occur generally within $20 \mathrm{~m}$ of the shoreline. Groundwater flux estimates based on seepage meter measurements ranged from $2.86 \times 10^{8}$ to $4.33 \times 10^{8} \mathrm{~m}^{3}$ annually and are comparable to estimates made using radon, a simple water-budget method, and estimates derived by using Darcy's Law and previously published general aquifer characteristics of the area. The lower groundwater flux estimate (equal to about $9 \mathrm{~m}^{3} \mathrm{~s}^{-1}$ ), which assumed the narrowest groundwater discharge zone $(20 \mathrm{~m})$ of three zone widths selected for an area west of New Bern, North Carolina, most closely agrees with groundwater flux estimates made using radon $\left(3-9 \mathrm{~m}^{3} \mathrm{~s}^{-1}\right)$ and Darcy's Law (about $9 \mathrm{~m}^{3} \mathrm{~s}^{-1}$ ). A groundwater flux of $9 \mathrm{~m}^{3} \mathrm{~s}^{-1}$ is about $40 \%$ of the surface-water flow to the Neuse River estuary between Streets Ferry and the mouth of the estuary and about $7 \%$ of the surface-water inflow from areas upstream. Estimates of annual nitrogen (333 tonnes) and phosphorus (66 tonnes) fluxes from groundwater to the estuary, based on this analysis, are less than $6 \%$ of the nitrogen and phosphorus inputs derived from all sources (excluding oceanic inputs), and approximately $8 \%$ of the nitrogen and $17 \%$ of the phosphorus annual inputs from
\end{abstract}

\section{T. B. Spruill $(\bowtie)$}

U.S. Geological Survey, North Carolina Water Science Center, 3916 Sunset Ridge Road,

Raleigh, NC 27607, USA

e-mail: tspruill@usgs.gov

J. F. Bratton

U.S. Geological Survey, Woods Hole Science Center,

384 Woods Hole Rd.,

Woods Hole, MA 02543, USA surface-water inflow to the Neuse River estuary assuming a mean annual precipitation of $1.27 \mathrm{~m}$. We provide quantitative evidence, derived from three methods, that the contribution of water and nutrients from groundwater discharge to the Neuse River estuary is relatively minor, particularly compared with upstream sources of water and nutrients and with bottom sediment sources of nutrients. Locally high groundwater discharges do occur, however, and could help explain the occurrence of localized phytoplankton blooms, submerged aquatic vegetation, or fish kills.

Keywords Groundwater flux · Estuaries · Nutrients · Nitrogen · Phosphorus · Groundwater - Water budget . Seepage meter $\cdot$ Eutrophication $\cdot$ Nutrient loading

\section{Introduction}

Groundwater inflow to estuaries has been, until recently, one of the least studied and, consequently, one of the least understood sources of nutrients to estuaries. In the late 1970s, Lee (1977) measured groundwater seepage using a seepage meter in lakes and estuaries in various areas of the United States, including a coastal sound in North Carolina. In the early 1980s, Bokuniewicz (1980) estimated groundwater inflow to the Great South Bay in New York using a seepage meter of the same design used by Lee (1977). Later, Capone and Bautista (1985) used groundwater flux estimates by Bokuniewicz (1980) to conclude that more than $20 \%$ of the nitrogen contributed by surface runoff to Great South Bay was derived from groundwater. After recognizing the potential importance of groundwater in contributing nutrients to coastal ecosystems, others began investigating the phenomenon in a variety of coastal settings (Reay et al. 1992; Staver and Brinsfield 1996; 
Portnoy et al. 1998; Corbett et al. 1999). A recent collaborative paper between more than 20 scientific institutions worldwide focused on investigating the role of groundwater in marine systems by multiple assessment methodologies (Burnett et al. 2006). This latter paper demonstrates a universal recognition by environmental scientists and managers of the need to quantify groundwater in coastal areas for implementation of effective management strategies.

Although several of these previous studies have addressed groundwater discharge in estuaries of the midAtlantic and northeastern United States, few studies have been directed toward understanding the role of groundwater in estuarine systems of the southeastern United States until recently. In addition, no studies in the published literature have attempted to measure groundwater and associated nutrient inflows to an estuarine watershed sufficiently to quantify groundwater contribution in the context of a water and nutrient budget.

In this paper, we quantify groundwater discharge and associated nutrient delivery to the Neuse River estuary (NRE), an estuary located in the Coastal Plain of the southeastern United States that suffers from severe eutrophication impacts. We describe the results of a study conducted between April 2004 and September 2005 to measure groundwater discharge in the NRE by using seepage meters and piezometers and to integrate the results with those of other geophysical and geochemical techniques employed in parallel studies to better understand the importance of groundwater in the NRE. Specific study objectives were to (1) estimate the discharge of groundwater and nutrients to the NRE, (2) broadly characterize spatial variability of groundwater discharge and nutrient flux to the NRE, (3) compare estimates of nutrient flux from groundwater with benthic nutrient flux estimates by other researchers, and (4) compare groundwater flux to the NRE measured by conventional seepage meters (Lee 1977; Bokuniewicz 1980) with groundwater fluxes estimated by other common methods, including a water budget developed previously for the Coastal Plain of North Carolina (Wilder et al. 1978) and a Darcy's Law estimate based on general hydrogeologic and environmental characteristics of the NRE. The relatively simple hydrologic principles that we apply in our analysis here of the NRE, coupled with currently available field technologies, can be used effectively to estimate reasonable regional groundwater and nutrient fluxes in many other estuarine systems.

\section{Site Description and Background}

The Neuse River basin (Fig. 1) is one of four major river basins that drain into the Albemarle-Pamlico estuarine system in North Carolina. The Albemarle-Pamlico estuarine system is the second largest estuarine system in the United States and provides critical habitat for numerous fish and shellfish species along the mid-Atlantic region of the United States (Paerl et al. 1995). The Neuse River estuary (NRE) extends from approximately $10 \mathrm{~km}$ west and upstream from New Bern, North Carolina, to about $45 \mathrm{~km}$ east and downstream from New Bern, where it enters Pamlico Sound (Fig. 1). Effects of eutrophication have been observed and documented by many researchers since the late 1970s. Principal problems associated with eutrophic conditions in the NRE include the occurrence of nuisance algal blooms (Paerl 1983) and fish kills and toxic dinoflagellate outbreaks during the 1990s (Bowen and Hieronymus 2000; Burkholder 2001). Research in the 1980s identified excess nitrogen and phosphorus loads into the estuary as a major cause of eutrophication (Tedder et al. 1980; Paerl 1983; Paerl et al. 1990), although during the mid-1990s, nitrogen was recognized as the primary growth-limiting nutrient in the middle and lower parts of the estuary (Paerl et al. 1995; Luettich et al. 2000). More recently, researchers have reported that control of both nutrients will be necessary to effectively manage water quality in the entire NRE (Paerl et al. 2004; Burkholder et al. 2006).

Chemicals entering estuarine waters, including nutrients from a watershed, originate from either diffuse or point sources. Although previous studies indicate that both point and nonpoint pollution sources contribute nutrients, nonpoint sources compose the larger portion of nutrient inputs to the river basins draining into the AlbemarlePamlico estuarine system (Dodd et al. 1992; McMahon and Woodside 1997). Excess nitrogen and phosphorus can cause eutrophication of streams and estuaries in the Albemarle-Pamlico drainage basin (Spruill et al. 1998), although nitrogen has been identified as a principal limiter of phytoplankton growth and primary production in many estuarine environments, including the NRE (Paerl et al. 1995). An estuary receives water containing nutrients and other chemicals from a variety of environmental sources, including precipitation falling directly onto the estuary, seawater moving periodically landward from the ocean as a result of lunar or wind-driven tides, freshwater draining from watersheds upstream into the estuary, water draining coastal plain tributary watersheds to the estuary, nutrients remobilized from bed sediments, and finally, groundwater moving directly from shallow aquifers into the estuary from areas adjacent to the estuary, such as streambeds or along the estuarine shoreline.

In the most recent work conducted in the NRE (Luettich et al. 2000), which addressed strategies to improve water quality in the Neuse River and estuary, groundwater was considered as a possible source of nutrients to the estuary. 
Fig. 1 Location of the Neuse River basin and Neuse River estuary. The Albemarle-Pamlico basin and Albemarle-Pamlico estuarine system are shown in the inset map

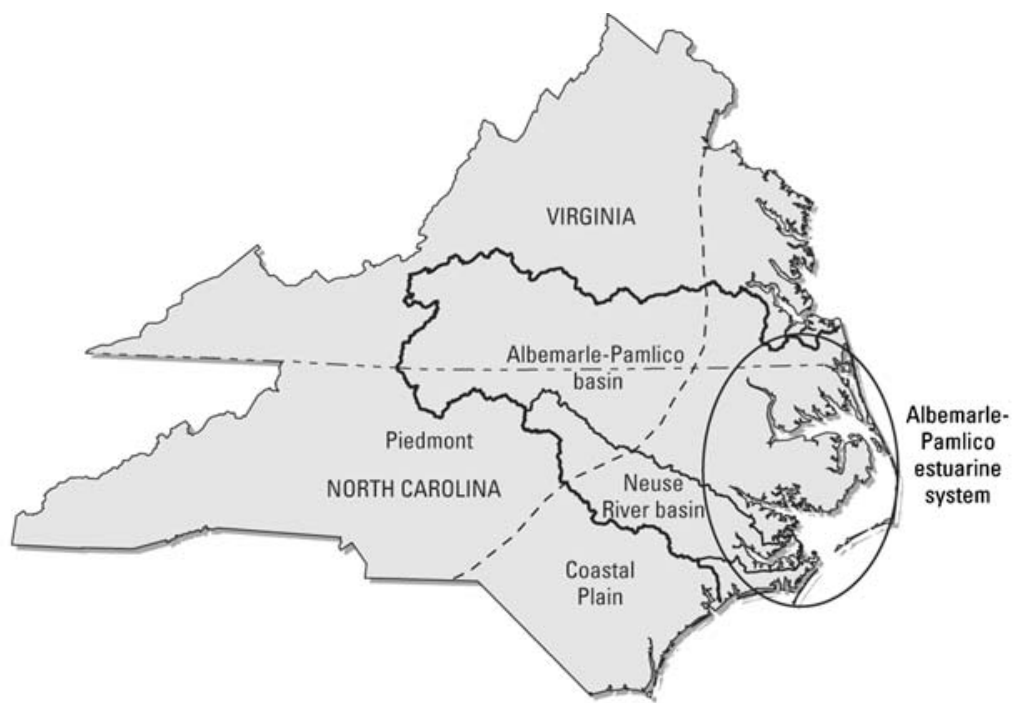

LOCATION OF NEUSE RIVER BASIN WITHIN THE ALBEMARLE-PAMLICO BASIN, PIEDMONT AND COASTAL PLAIN PHYSIOGRAPHIC PROVINCES, AND ALBEMARLE-PAMLICO ESTÚARINE SYSTEM IN NORTH CAROLINA AND VIRGINIA

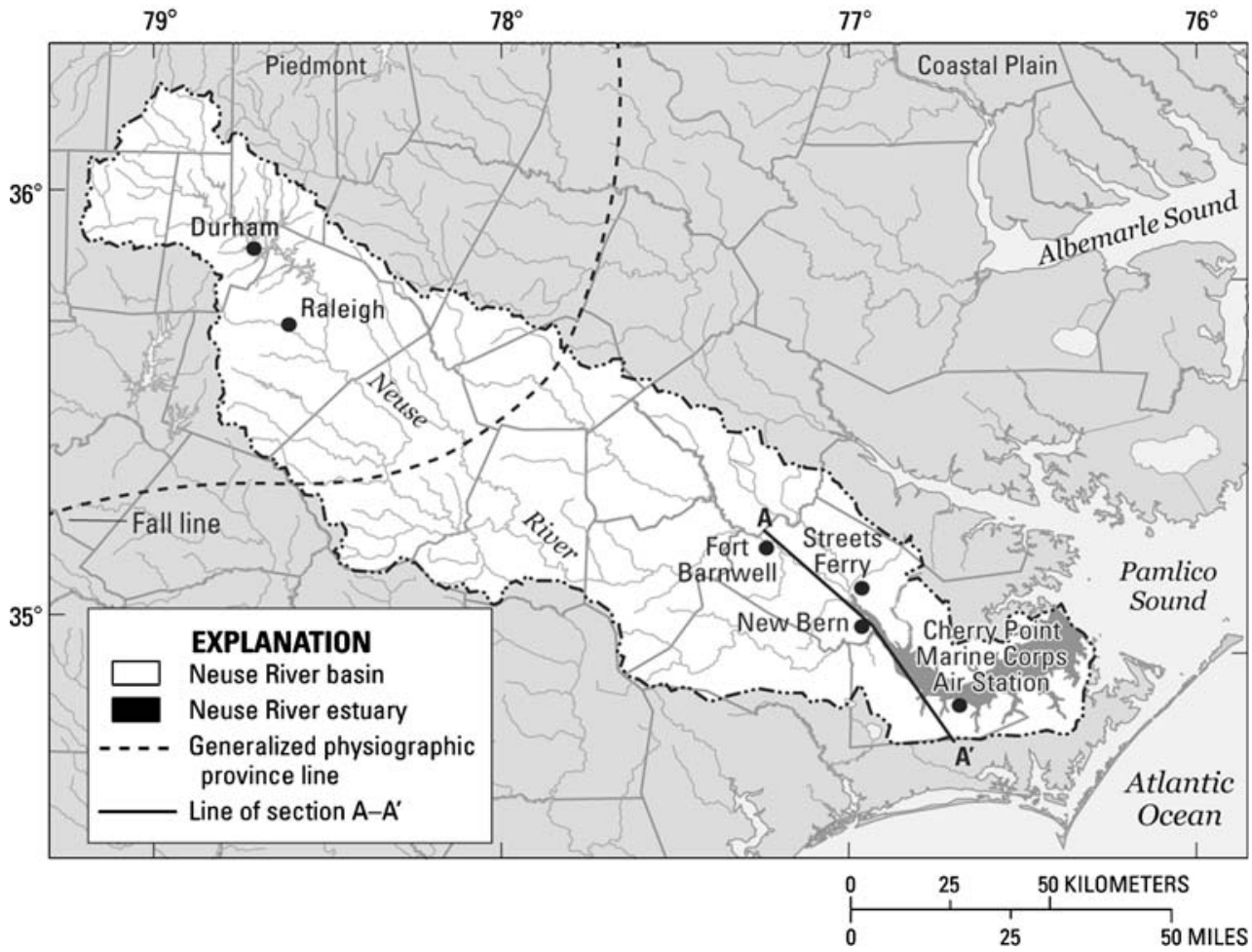

The investigators concluded that groundwater is not a significant source of nutrients (Luettich et al. 2000) and that nutrients enter the water column primarily by diffusion from the bed of the estuary. This conclusion was reached based on information from nine $30-\mathrm{cm}$ sediment cores collected from mid-channel in the estuary upstream from New Bern to near Minnesott Beach (Fig. 2) where pore water was extracted and salinity was measured. The lack of significant dilution of pore water with depth in all but one (near New Bern) of the nine cores indicated to the researchers that fresh groundwater was not discharging in substantial quantities to the estuary and, therefore, was not a significant source of nutrients (Luettich et al. 2000).

Luettich et al. (2000) concluded that diffusion of nutrients from the bed of the estuary into the water column was the primary source of nitrogen to the NRE. Estimates of average nitrogen flux (as ammonium) from the bed of the estuary into the water column ranged from 0.9 to 5.4 mmol m $\mathrm{m}^{-2} \mathrm{~d}^{-1}$, or an average of $3.2 \mathrm{mmol} \mathrm{m}^{-2} \mathrm{~d}^{-1}$ based on six separate studies (Table 1). In one of the studies, Fisher et al. (1982) found that the highest rates of ammonium regeneration occurred in parts of the estuary with fine- 
Fig. 2 Sediment lithology and measured unit groundwater fluxes in the Neuse River estuary. Sediment lithology modified from Luettich et al. (2000). Letters next to symbols indicate: $A$ Ammonium-nitrogen flux greater than $18 \mathrm{mmol} \mathrm{m}^{-2} \mathrm{~d}^{-1}$, $P$ orthophosphate-phosphorus flux greater than $0.5 \mathrm{mmol} \mathrm{m}^{-2} \mathrm{~d}^{-1}$

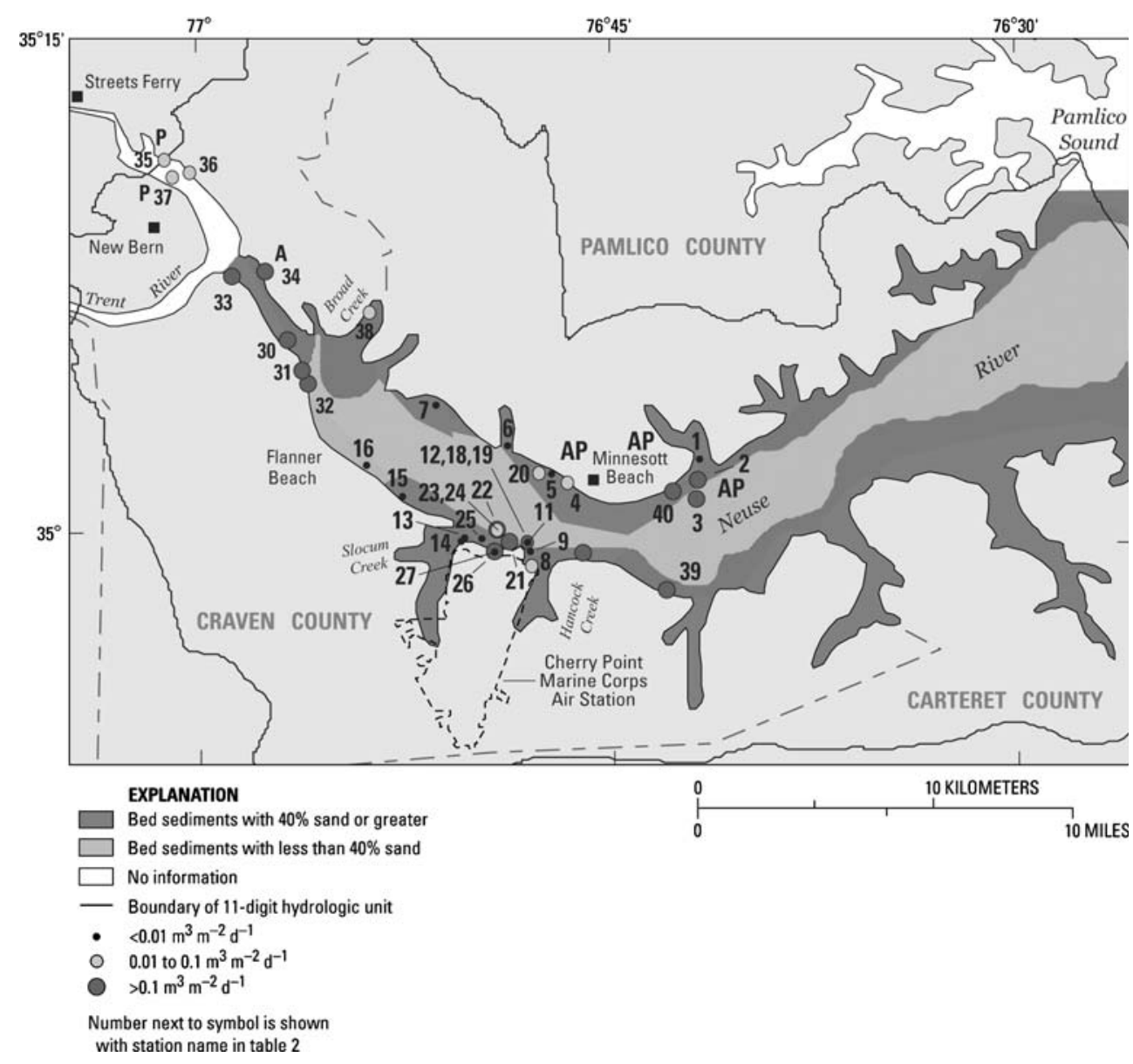

Table 1 Groundwater and benthic flux estimates of nutrients from the Neuse River estuary

\begin{tabular}{|c|c|c|c|c|c|c|c|c|}
\hline $\begin{array}{l}\text { Literature } \\
\text { source }\end{array}$ & Estuary & Method & $\begin{array}{l}\mathrm{NH}_{4} \text { flux } \\
\left(\mathrm{mmol} \mathrm{m}^{-2}\right. \\
\left.\mathrm{d}^{-1}\right)\end{array}$ & $\begin{array}{l}\mathrm{NH}_{4}-\mathrm{N} \text { unit } \\
\text { flux }\left(\mathrm{mg} \mathrm{m}^{-2}\right. \\
\left.\mathrm{d}^{-1}\right)\end{array}$ & $\begin{array}{l}\mathrm{NH}_{4}-\mathrm{N} \\
\text { flux } \\
\text { (tonnes } \\
\mathrm{yr}^{-1} \text { ) }\end{array}$ & $\begin{array}{l}\mathrm{PO}_{4} \text { flux } \\
\left(\mathrm{mmol} \mathrm{m}{ }^{-2}\right. \\
\left.\mathrm{d}^{-1}\right)\end{array}$ & $\begin{array}{l}\mathrm{PO}_{4}-\mathrm{P} \\
\text { flux } \\
\left(\mathrm{mg} \mathrm{m}{ }^{-2}\right. \\
\left.\mathrm{d}^{-1}\right)\end{array}$ & $\begin{array}{l}\mathrm{PO}_{4}-\mathrm{P} \\
\text { flux } \\
\text { (tonnes } \\
\mathrm{yr}^{-1} \text { ) }\end{array}$ \\
\hline $\begin{array}{l}\text { Matson et al. } \\
\text { (1983) }\end{array}$ & NRE & $\begin{array}{c}\text { Pore-water } \\
\text { gradient }\end{array}$ & 0.9 & 12.6 & 1,044 & 0.10 & 3.0 & 249 \\
\hline $\begin{array}{l}\text { Fisher et al. } \\
\text { (1982) }\end{array}$ & NRE & In situ chamber & 5.4 & 75.6 & 6,263 & 0.34 & 10.2 & 845 \\
\hline $\begin{array}{l}\text { Rizzo and } \\
\text { Christian (1996) }\end{array}$ & NRE & Unstirred cores & 2.4 & 33.6 & 2,784 & 0.38 & 11.4 & 944 \\
\hline $\begin{array}{l}\text { Sauber (1998); } \\
\text { Luettich et al. } \\
(2000)\end{array}$ & NRE & $\begin{array}{l}\text { In situ chamber; } \\
\text { lab chamber }\end{array}$ & 2.7 & 37.8 & 3,132 & NA & NA & $\mathrm{NA}$ \\
\hline $\begin{array}{l}\text { Haruthunian } \\
\text { (1997) }\end{array}$ & NRE & $\begin{array}{c}\text { Pore-water } \\
\text { gradient }\end{array}$ & 4.0 & 56.0 & 4,639 & NA & NA & NA \\
\hline $\begin{array}{l}\text { Average for six } \\
\text { NRE studies }\end{array}$ & NRE & $\begin{array}{l}\text { Various methods } \\
\text { (six studies listed } \\
\text { above) }\end{array}$ & 3.2 & 44.8 & 3,712 & NA & NA & NA \\
\hline This study & NRE & $\begin{array}{l}\text { Groundwater flux } \\
\text { (meter) }\end{array}$ & NA & 94.5 & 333 & 0.63 & 18.9 & 66 \\
\hline
\end{tabular}


grained sediment and a high content of organic material, whereas ammonium flux was zero in coarse-grained sands with a low content of organic material. Based on sedimenttype distribution in the NRE (Fig. 2), about $50-70 \%$ of the area has fine-grained material (sediments having less than $40 \%$ sand) in the center of the estuary and sandy material (sediments with more than $40 \%$ sand) is confined to nearshore areas. Luettich et al. (2000) reported that about 7,000 tonnes of nitrogen are contained in the upper $2 \mathrm{~cm}$ of sediment in the NRE. Thus, assuming that half of the estuary surface area of $4.55 \times 10^{8} \mathrm{~m}^{2}$ (Buzzelli and Christian 2001 ) is covered with nitrogenous organic debris and serves as a source of nitrogen, between approximately 1,000 and 6,200 tonnes of nitrogen annually could be regenerated from sediment to the water column based on benthic sediment-flux estimates for the NRE (Table 1). This amount ranges from about $25 \%$ to more than $150 \%$ of the total annual average riverine input of nitrogen, assuming a surface-water flux to the NRE of about 4,000 tonnes for an average year based on several published annual nitrogen loads - 4,400 tonnes reported for 1992-1996 (North Carolina Department of Environment and Natural Resources 2001), 4,400 tonnes reported for 2000 (Spruill et al. 2005), or 1,900 tonnes for 1986 (a dry year) and 6,170 tonnes for 1987 (a wet year) estimated by Buzzelli and Christian (2001). Previously published phosphorus fluxes from the bed sediments were approximately 940 tonnes $\mathrm{yr}^{-1}$ (Rizzo and Christian 1996; Table 1), 850 tonnes $\mathrm{yr}^{-1}$ (Fisher et al. 1982; Table 1), and almost 250 tonnes $\mathrm{yr}^{-1}$ (Matson et al. 1983; Table 1). These amounts are $220 \%$ and $65 \%$, respectively, of the average riverine input of phosphorus based on a transported load of 385 tonnes for 2000 (Spruill et al. 2005).
Although Luettich et al. (2000) did not find that groundwater inflow was significant in the NRE, other researchers have measured groundwater inflow in other estuarine systems and determined that it ranged from less than $0.01 \mathrm{~m}^{3} \mathrm{~m}^{-2} \mathrm{~d}^{-1}$ in the Chesapeake Bay (Reay at al. 1992) to more than $0.23 \mathrm{~m}^{-3} \mathrm{~m}^{-2} \mathrm{~d}^{-1}$ in Biscayne Bay, Florida (Halley et al. 2005; Table 2). However, none of the published research attempted to quantify groundwater inputs in the context of a total estuarine water budget. Groundwater discharge to estuaries typically is greatest along the shoreline and decreases with increasing distance from the shoreline (Bokuniewicz 1980). In saltwater environments, dense saline water restricts the movement of fresh groundwater offshore because of salinity-related density gradients (Bear 1979), which form a saltwaterfreshwater interface (Fig. 3). The conclusions of Luettich et al. (2000), which are consistent with what is known about groundwater flow into estuaries, were that groundwater flow was not significant in the center of the Neuse River estuary at nine study sites. Their investigation did not include the shoreline area, however, where groundwater would be expected to discharge. Therefore, it is possible that their analysis underestimated the amount that groundwater contributes to the nutrient budget of the estuary and the relative importance of groundwater to other nutrient sources in the NRE.

A variety of approaches beyond benthic-flux measurements and pore-water salinity profiling have been developed in recent years to study groundwater processes. These include integrated marine seismic and marine electrical resistivity surveys to establish submarine groundwater salinity distribution in a hydrogeologic framework (Krantz et al. 2004; Manheim et al. 2004); coring and sampling in

Table 2 Groundwater flux estimates from selected estuaries

\begin{tabular}{|c|c|c|c|c|}
\hline Literature source & Estuary & Method & $\begin{array}{l}\text { Width of discharge } \\
\text { zone in meters }\end{array}$ & $\begin{array}{l}\text { Seepage rate } \\
\mathrm{m}^{3} \mathrm{~m}^{-2} \mathrm{~d}^{-1}\end{array}$ \\
\hline Schwartz (2003) & Delaware River Basin & Radon & NA & 0.10 \\
\hline Bokuniewicz (1980) & Great South Bay, NY & Meter & 30 & 0.04 \\
\hline Crusius et al. (2005) & Nauset Marsh, MA & Radon & NA & 0.18 \\
\hline Nowicki et al. (1999) & Nauset Marsh, MA & Meter & NA & $0.006-0.042$ \\
\hline Halley et al. (2005) & Biscayne Bay, FL & Meter & $100-1,000$ & 0.23 \\
\hline Reay et al. (1992) & Cherrystone Inlet, VA & Meter & 50 & $0.0007-0.09$ \\
\hline $\begin{array}{l}\text { Staver and Brinsfield } \\
\text { (1996) }\end{array}$ & Wye River Estuary, VA (late summer) & $\begin{array}{l}\text { Darcy's Law; } \\
\text { hydraulic properties }\end{array}$ & 5 & 0.011 \\
\hline $\begin{array}{l}\text { Staver and Brinsfield } \\
\text { (1996) }\end{array}$ & Wye River Estuary, VA (late winter) & $\begin{array}{l}\text { Darcy's Law; } \\
\text { hydraulic properties }\end{array}$ & 10 & 0.052 \\
\hline This study & Neuse River Estuary & Meter & $10-50$ & $\begin{array}{l}\text { Typical } 0.09 \\
\text { Range }(<0.01-0.43)\end{array}$ \\
\hline Lee (1977) & Bogue Sound, NC & Meter & NA & $\begin{array}{l}\text { Median } 0.04 \\
\text { Range }(0-0.11)\end{array}$ \\
\hline
\end{tabular}

NA Not analyzed or applicable 
a Estuary more saline

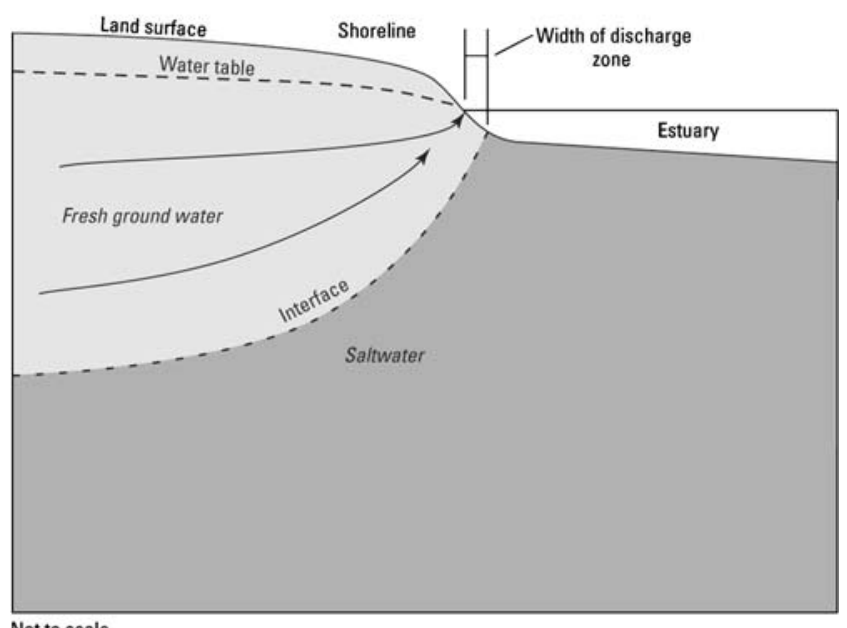

Not to scale

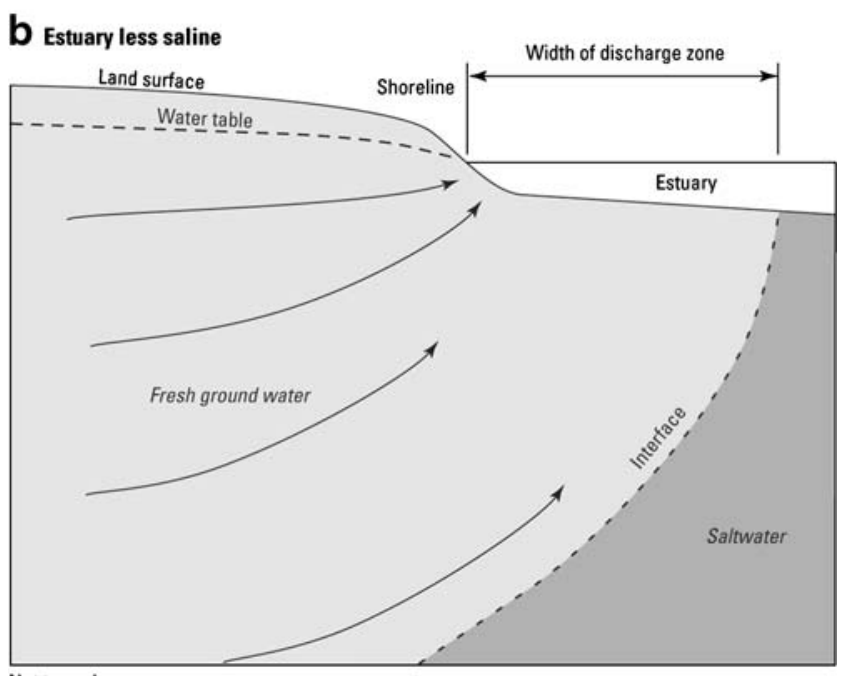

Not to scale

Fig. 3 Comparison of position of saltwater-freshwater interface and width of groundwater discharge zone where fresh groundwater discharges to an estuary having water that is a more saline and $\mathbf{b}$ less saline. Lightgray area represents aquifer sediments saturated with fresh groundwater. Dark gray area represents aquifer sediments saturated with saltwater from the estuary. Modified from Fetter (2001)

offshore wells to analyze nutrients, stable isotopes, and groundwater age tracers, including tritium, tritium/helium, sulfur hexafluoride, and chlorofluorocarbons (Bratton et al. 2004); and natural groundwater tracer studies using radon gas emanation to evaluate groundwater discharge locations, rates of discharge, and time variability over tidal cycles (Crusius et al. 2005). These and many other useful techniques for measuring and understanding groundwater in coastal regions, some of which were incorporated in our study of the NRE, are presented in Burnett et al. (2006). Because of the large spatial and temporal variability of groundwater discharge in coastal areas (Burnett et al. 2006), the use of several techniques will typically be necessary to reasonably quantify groundwater discharge.
To understand the role that groundwater plays in the ecology of any estuary, it is prerequisite to understand the regional hydrogeology. The principal shallow geologic formations of the NRE between Fort Barnwell, located upstream and west of Streets Ferry and defining the upper limit of the NRE, and the Cherry Point Marine Corps Air Station (section $\mathrm{A}^{-} \mathrm{A}^{\prime}$ in Fig. 1) are shown in Fig. 4. The surficial aquifer, composed of Pleistocene and recent sediments (Winner and Coble 1996), covers most of the study area except where the sediments have been eroded by the river. These sediments, ranging from 10 to $30 \mathrm{~m}$ in thickness and thickening toward the east, provide the bulk of the groundwater draining to the estuary. Hydraulic conductivity of the surficial sediments is estimated to be about $10 \mathrm{~m} \mathrm{~d}^{-1}$ (Winner and Coble 1996). Based on information presented in Giese et al. (1992), groundwater in the surficial aquifer discharges to the estuary along flow paths generally perpendicular to the central axis of the NRE.

The Yorktown confining unit, which is at least 3-10 m thick in the vicinity of Cherry Point (Eimers et al. 1994), underlies the surficial aquifer and generally averages $8 \mathrm{~m}$ in thickness in the Coastal Plain (Giese et al. 1992). The Yorktown confining unit serves as the bed of the NRE near New Bern and eastward (Floyd 1969; Fig. 4) to the mouth of the estuary. Very little groundwater likely discharges to the NRE from the Yorktown aquifer except where buried paleochannels, such as one located near Cherry Point (Daniel et al. 1996; Wrege and Jen 2004), locally allow water to move between aquifers through the breached confining units. The local absence and discontinuity of confining units near Cherry Point, which were later determined to be the result of incising by the paleochannel, were first noted by Lloyd and Daniel (1988). The Yorktown confining unit merges with the Pungo River confining unit near New Bern (Fig. 4). It does not appear from the information shown in Fig. 4 that the Pungo River aquifer is connected to the Neuse River directly. Most of the groundwater discharge to the NRE probably is derived primarily from the surficial aquifer. West of New Bern and near Streets Ferry, however, parts of the upper Castle Hayne aquifer, composed largely of limestone, along with the surficial aquifer may form part of the streambed of the upper NRE. The hydraulic conductivity of the limestone may be as high as $60 \mathrm{~m} \mathrm{~d}^{-1}$ (Winner and Coble 1996). Hydraulic conductivity of deposits underlying the NRE west of New Bern is conservatively estimated to be $20 \mathrm{~m} \mathrm{~d}^{-1}$, a combination of hydraulic properties of the Castle Hayne and surficial aquifers.

Bottom sediments of the NRE are composed of material ranging from coarse sands along the shoreline and estuary west and upstream from New Bern, to fine silts and clays that cover most of the axial basin of the open estuary beyond about $8 \mathrm{~km}$ downstream from New Bern (Luettich 
Fig. 4 Principal aquifers and confining units that underlie the Neuse River estuary. Trace for cross section is shown in Fig. 1. Modified from Floyd (1969), incorporating information from Giese et al. (1992), Eimers et al. (1994), and Winner and Coble (1996)

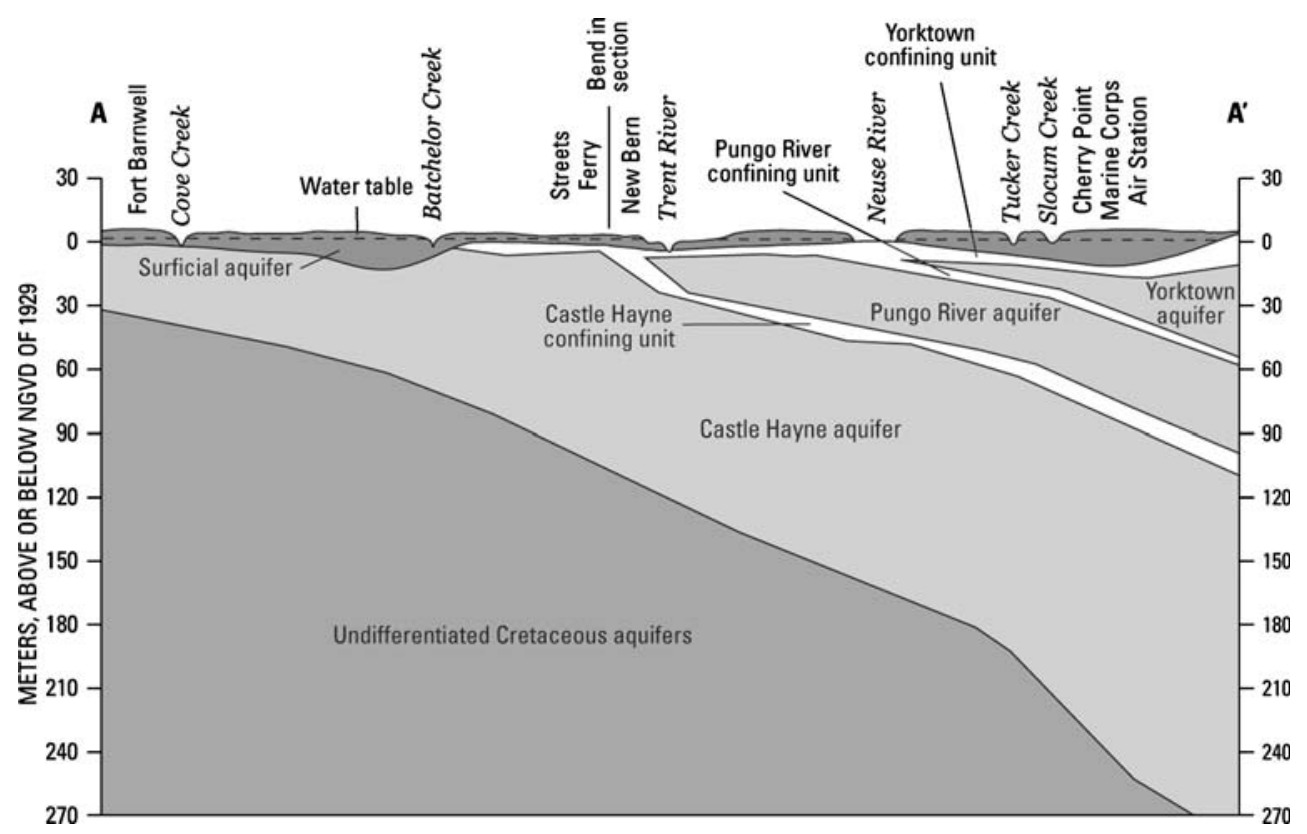

et al. 2000). Fine-grained material with substantial organic carbon (Luettich et al. 2000) settles out where the NRE widens downstream from New Bern, and such sediments dominate the lithology of the bed material throughout the deeper parts $(>2 \mathrm{~m})$ of the middle and lower estuary (Fig. 2). These fine organic-rich sediments rest on the Yorktown or Pungo River confining units from New Bern eastward, forming very low permeability material in the central part of the estuary. Medium to coarse sands that compose the surficial aquifer have been eroded and removed by the main channel of the Neuse River (Wells 1989), but the sands left behind form the banks and grade into the bed along the shoreline, except along the south bank between Broad Creek, a tributary on the north bank where the estuary widens, and Flanner Beach (Fig. 2).

\section{Methods}

Measurements of groundwater and nutrient flux were made at 36 sites in the Neuse River estuary, North Carolina (Table 3; Fig. 2). Seven of these sites (NR34-40, Table 3; Fig. 2) were selected to evaluate the relations between distance from the shoreline and discharge and head difference between surface and groundwater. Head measurements of groundwater and surface water were made using a potentiomanometer (Winter et al. 1988), and groundwater discharge was measured using a conventional seepage meter (Lee 1977) at all sites between April 2004 and September 2005. Minipiezometers were driven to a depth ranging between 0.3 and $1.2 \mathrm{~m}$ beneath the streambed for head measurements. Seepage was measured by placing the meter (having an area of $0.064 \mathrm{~m}^{2}$ ) with an empty collapsed plastic collection bag on the bottom of the estuary within about $2 \mathrm{~m}$ of the minipiezometer and leaving the meter in place for 8 to 1,330 min during the April and June 2004 sampling periods. Meters penetrated the bottom sediments about $0.18 \mathrm{~m}$ with a head space of approximately 6-12 mm. During September 2005, seepage meters were left in place 20-30 min before recording seepage volumes. Seepage was measured along the shoreline at sites where the surface-water depth was less than about $1 \mathrm{~m}$. The volume of water that seeped into the collection bag during the sampling period was then measured, using a $100-$ or $500-\mathrm{mL}$ graduated cylinder, and recorded. Where surface-water depths were greater than $1 \mathrm{~m}$, only head measurements were made. Where head differences were not detectable, seepage was assumed to be minimal and assigned a value of $<0.01$. Unit groundwater fluxes presented in Table 3 are derived from one to three measurements made at each site. Head measurements, recorded in triplicate, were considered accurate to within $\pm 9 \mathrm{~mm}$; the median values are given in Table 3. Surface-water specific conductance and temperature recorded at each site are presented in Table 3.

Water-quality information was obtained from 15 of the 36 sites to estimate nutrient flux to the estuary from groundwater discharge (Table 4). Water samples were collected from the minipiezometer placed between 0.3 and $1.2 \mathrm{~m}$ beneath the bed of the estuary to characterize the water quality of groundwater discharging to the estuary; a peristaltic pump was used to collect water from the minipiezometers at each site. Nutrient samples were filtered through a $0.45-\mu \mathrm{m}$ filter into sample bottles, chilled, and 
Table 3 Groundwater flux measurements, surface-water temperature, and specific conductance in the Neuse River Estuary, April 2004September 2005

\begin{tabular}{|c|c|c|c|c|c|c|}
\hline Station name & Date & $\begin{array}{l}\text { Surface-water } \\
\text { temperature }\left({ }^{\circ} \mathrm{C}\right)\end{array}$ & $\begin{array}{l}\text { Surface-water } \\
\text { conductance }\left(\mu \mathrm{S} / \mathrm{cm}^{-1}\right)\end{array}$ & $\begin{array}{l}\text { Meters } \\
\text { from shore }\end{array}$ & $\begin{array}{l}\text { Unit groundwater flux } \\
\left(\mathrm{m}^{3} \mathrm{~m}^{-2} \mathrm{~d}^{-1}\right)\end{array}$ & $\begin{array}{l}\text { GW-SW head } \\
\text { difference }(\mathrm{mm})\end{array}$ \\
\hline PA-155 NR1 & $04 / 19 / 04$ & 22.3 & 7,590 & 1 & $<0.01$ & ND \\
\hline PA-156 NR2 & $04 / 21 / 04$ & 18.5 & 5,810 & 1 & 0.38 & 36.48 \\
\hline PA-157 NR3 & $04 / 20 / 04$ & NM & NM & 1 & 0.22 & -9.12 \\
\hline $\mathrm{PA}-158 \mathrm{NR} 4$ & $04 / 20 / 04$ & 23.3 & 3,850 & 1 & 0.04 & ND \\
\hline PA-159 NR5 & $04 / 20 / 04$ & 27.0 & 4,000 & 2 & $<0.01$ & ND \\
\hline PA-160 NR6 & $04 / 20 / 04$ & 21.6 & 2,980 & 10 & $<0.01$ & ND \\
\hline PA-161 NR7 & $04 / 20 / 04$ & 22.6 & 1,730 & 12 & $<0.01$ & -9.12 \\
\hline CR-628 NR8 & $04 / 21 / 04$ & 21.0 & 7,700 & 10 & 0.05 & 73 \\
\hline CR-629 NR9 & $04 / 21 / 04$ & 19.5 & 10,100 & 90 & $<0.01$ & ND \\
\hline CR-630 NR11 & $04 / 21 / 04$ & 23.2 & 8,600 & 20 & $<0.01$ & ND \\
\hline CR-631 NR12 & $04 / 21 / 04$ & 20.2 & NM & 1 & 0.05 & 21.28 \\
\hline CR-632 NR13 & $04 / 21 / 04$ & 20.3 & 9,600 & 500 & $<0.01$ & ND \\
\hline CR-633 NR14 & $04 / 21 / 04$ & NM & 7,480 & 400 & $<0.01$ & 9.12 \\
\hline CR-635 NR16 & $04 / 21 / 04$ & 18.2 & 10,100 & 400 & $<0.01$ & ND \\
\hline CR-638 NR18 & $06 / 22 / 04$ & 29.6 & 20,020 & 30 & 0.10 & 12.16 \\
\hline CR-639 NR19 & $06 / 22 / 04$ & $\mathrm{NM}$ & NM & 32 & 0.02 & ND \\
\hline CR-640 NR20 & $06 / 22 / 04$ & 30.4 & 19,857 & 2 & 0.04 & 36.48 \\
\hline CR-641 NR21 & $06 / 22 / 04$ & 28.4 & 20,709 & 2 & 0.16 & 12.16 \\
\hline CR-642 NR22 & $06 / 22 / 04$ & 28.2 & 20,670 & 5 & 0.15 & 9.12 \\
\hline CR-643 NR23 & $06 / 22 / 04$ & 28.3 & 20,970 & 4 & 0.05 & 27.36 \\
\hline CR-644 NR24 & $06 / 22 / 04$ & 28.4 & 20,858 & 4 & 0.06 & ND \\
\hline CR-645 NR25 & $06 / 23 / 04$ & 28.1 & 19,500 & 500 & $<0.01$ & ND \\
\hline CR-646 NR26 & $06 / 23 / 04$ & 30.7 & 20,100 & 2 & 0.20 & -106.4 \\
\hline CR-647 NR27 & $06 / 23 / 04$ & 30.5 & 19,926 & 2 & $<0.01$ & 12.16 \\
\hline CR-650 NR30 & $10 / 20 / 04$ & 21.5 & 1,355 & 1 & 0.16 & 45.6 \\
\hline CR-651 NR31 & $10 / 20 / 04$ & 21.6 & 2,523 & 1 & 0.10 & $\mathrm{NM}$ \\
\hline CR-652 NR32 & $10 / 20 / 04$ & 21.8 & 3,014 & 1 & 0.36 & NM \\
\hline CR-653 NR33 & $10 / 21 / 04$ & NM & NM & 1 & 0.17 & $\mathrm{NM}$ \\
\hline CR-654 NR34 & $10 / 21 / 04$ & 20.0 & 2,045 & 1 & 0.43 & 27.36 \\
\hline CR-654 NR34MP0 & $09 / 27 / 05$ & 27.3 & 6,924 & 1 & 0.05 & $\mathrm{ND}$ \\
\hline CR-654 NR34MP10 & $09 / 27 / 05$ & $\mathrm{NM}$ & NM & 3 & 0.16 & $\mathrm{NM}$ \\
\hline CR-654 NR34MP40 & $09 / 27 / 05$ & NM & NM & 12 & 0.17 & $\mathrm{NM}$ \\
\hline CR-655 NR35MP0 & $09 / 21 / 05$ & 27.4 & 266 & 0 & 0.08 & ND \\
\hline CR-655 NR35MP10 & $09 / 21 / 05$ & NM & NM & 3 & 0.08 & $\mathrm{NM}$ \\
\hline CR-655 NR35MP17 & $09 / 21 / 05$ & $\mathrm{NM}$ & NM & 5 & 0.08 & ND \\
\hline $\mathrm{CR}-656 \mathrm{NR} 36 \mathrm{MP} 0$ & $09 / 21 / 05$ & 28.0 & 2,360 & 0 & 0.04 & ND \\
\hline CR-656 NR36MP10 & $09 / 21 / 05$ & $\mathrm{NM}$ & NM & 3 & 0.11 & $\mathrm{NM}$ \\
\hline CR-656 NR36MP25 & $09 / 21 / 05$ & NM & NM & 8 & 0.08 & $\mathrm{NM}$ \\
\hline CR-656 NR37MP0 & $09 / 22 / 05$ & 26.9 & 1,492 & 0 & 0.07 & ND \\
\hline CR-656 NR37MP10 & $09 / 22 / 05$ & $\mathrm{NM}$ & NM & 3 & 0.09 & NM \\
\hline CR-656 NR37MP35 & $09 / 22 / 05$ & $\mathrm{NM}$ & NM & 11 & 0.08 & $\mathrm{NM}$ \\
\hline $\mathrm{CR}-656 \mathrm{NR} 38 \mathrm{MP} 0$ & $09 / 27 / 05$ & 28.6 & 10,678 & 0 & 0.07 & ND \\
\hline CR-656 NR38MP10 & $09 / 27 / 05$ & NM & NM & 3 & 0.11 & NM \\
\hline CR-656 NR38MP20 & $09 / 27 / 05$ & NM & NM & 6 & 0.11 & NM \\
\hline CR-656 NR39MP0 & $09 / 28 / 05$ & 25.3 & 19,223 & 0 & 0.13 & ND \\
\hline CR-656 NR39MP50 & $09 / 28 / 05$ & NM & NM & 16 & 0.22 & NM \\
\hline CR-656 NR39MP100 & $09 / 28 / 05$ & $\mathrm{NM}$ & NM & 30 & 0.12 & $\mathrm{NM}$ \\
\hline PA-166 NR40MP0 & $09 / 28 / 05$ & NM & NM & 0 & 0.25 & ND \\
\hline PA-166 NR40MP10 & $09 / 28 / 05$ & $\mathrm{NM}$ & NM & 3 & 0.06 & $\mathrm{NM}$ \\
\hline PA-166 NR40MP40 & $09 / 28 / 05$ & NM & NM & 12 & 0.16 & NM \\
\hline Minimum & & 18.2 & 266 & 0 & $<0.01$ & \\
\hline Mean & & 25.0 & 10,151 & 43 & 0.10 & \\
\hline Standard deviation & & 4.0 & 7,953 & 122 & 0.11 & \\
\hline Median & & 26.1 & 8,150 & 3 & $0.07(0.04-0.13)^{\mathrm{a}}$ & \\
\hline Maximum & & 30.7 & 20,970 & 500 & 0.43 & \\
\hline
\end{tabular}

${ }^{\text {a }} 95 \%$ confidence interval of median

$N M$ not measured, $N D$ no difference 
Table 4 Concentrations and estimated fluxes of selected nutrients from piezometer samples collected in the Neuse River estuary, April 2004September 2005

\begin{tabular}{|c|c|c|c|c|c|c|c|c|c|c|c|}
\hline $\begin{array}{l}\text { Station } \\
\text { name }\end{array}$ & Date & $\begin{array}{l}\text { Unit } \\
\text { flux }\left(\mathrm{m}^{3}\right. \\
\left.\mathrm{m}^{-2} \mathrm{~d}^{-1}\right)\end{array}$ & $\begin{array}{l}\text { Ortho-P } \\
(\mathrm{mg} \\
\left.\mathrm{L}^{-1}\right)\end{array}$ & $\begin{array}{l}\text { Ortho-P } \\
\text { (mg } \\
\mathrm{m}^{-2} \\
\mathrm{~d}^{-1} \text { ) }\end{array}$ & $\begin{array}{l}\text { Ortho-P } \\
\text { (mmol } \\
\mathrm{m}^{-2} \\
\mathrm{~d}^{-1} \text { ) }\end{array}$ & $\begin{array}{l}\mathrm{NH}_{4}-\mathrm{N} \\
(\mathrm{mg} \\
\left.\mathrm{L}^{-1}\right)\end{array}$ & $\begin{array}{l}\mathrm{NH}_{4}-\mathrm{N} \\
\left(\mathrm{mg} \mathrm{m} \mathrm{m}^{-2}\right. \\
\left.\mathrm{d}^{-1}\right)\end{array}$ & $\begin{array}{l}\mathrm{NH}_{4}-\mathrm{N} \\
(\mathrm{mmol} \\
\left.\mathrm{m}^{-2} \mathrm{~d}^{-1}\right)\end{array}$ & $\begin{array}{l}\text { Total } \\
\text { inorganic } \\
\mathrm{N}\left(\mathrm{mg} \mathrm{L}^{-1}\right)\end{array}$ & $\begin{array}{l}\text { Organic } \\
\mathrm{N}(\mathrm{mg} \\
\left.\mathrm{L}^{-1}\right)\end{array}$ & $\begin{array}{l}\text { Total } \\
\mathrm{N}(\mathrm{mg} \\
\left.\mathrm{L}^{-1}\right)\end{array}$ \\
\hline $\begin{array}{c}\text { PA-156 } \\
\text { NR2 }\end{array}$ & $04 / 21 / 04$ & 0.28 & 0.21 & 59.63 & 1.99 & 0.44 & 123.18 & 8.80 & 0.44 & 0.06 & 0.50 \\
\hline $\begin{array}{c}\text { PA-158 } \\
\text { NR4 }\end{array}$ & $04 / 20 / 04$ & 0.04 & 1.34 & 57.71 & 1.92 & 7.60 & 327.32 & 23.38 & 7.60 & 0.18 & 7.78 \\
\hline $\begin{array}{c}\text { CR-628 } \\
\text { NR8 }\end{array}$ & $04 / 21 / 04$ & 0.05 & 0.04 & 2.25 & 0.07 & 0.04 & 1.88 & 0.13 & 0.04 & 0.05 & 0.09 \\
\hline $\begin{array}{c}\text { CR-631 } \\
\text { NR12 }\end{array}$ & $04 / 21 / 04$ & 0.05 & 0.01 & 0.31 & 0.01 & 2.49 & 128.69 & 9.19 & 2.49 & 0.34 & 2.83 \\
\hline $\begin{array}{c}\text { CR-645 } \\
\text { NR25 }\end{array}$ & $06 / 23 / 04$ & 0.01 & 4.22 & 0.01 & 0.00 & 14.50 & 0.00 & 0.00 & 14.50 & 0.00 & 14.50 \\
\hline $\begin{array}{c}\text { CR-647 } \\
\text { NR27 }\end{array}$ & $06 / 23 / 04$ & 0.01 & 0.03 & 0.01 & 0.00 & 0.64 & 0.00 & 0.00 & 0.64 & 0.05 & 0.69 \\
\hline $\begin{array}{c}\text { CR-653 } \\
\text { NR33 }\end{array}$ & $10 / 21 / 04$ & 0.17 & 0.27 & 46.70 & 1.56 & 0.14 & 24.55 & 1.75 & 0.14 & 0.13 & 0.27 \\
\hline $\begin{array}{c}\text { CR-654 } \\
\text { NR34 }\end{array}$ & $10 / 21 / 04$ & 0.43 & 0.05 & 21.70 & 0.72 & 1.27 & 551.07 & 39.36 & 1.27 & 1.01 & 2.28 \\
\hline $\begin{array}{l}\text { CR-654 } \\
\text { NR34MP0 }\end{array}$ & $09 / 27 / 05$ & 0.05 & 0.05 & 2.54 & 0.08 & 1.08 & 57.24 & 4.09 & 1.08 & 0.73 & 1.81 \\
\hline $\begin{array}{l}\text { CR-655 } \\
\text { NR35MP0 }\end{array}$ & $09 / 21 / 05$ & 0.08 & 0.74 & 55.57 & 1.85 & 0.80 & 60.62 & 4.33 & 0.80 & 0.28 & 1.09 \\
\hline $\begin{array}{l}\text { CR-656 } \\
\text { NR36MP0 }\end{array}$ & $09 / 21 / 05$ & 0.04 & 0.40 & 13.89 & 0.46 & 0.25 & 8.74 & 0.62 & 0.25 & 0.36 & 0.61 \\
\hline $\begin{array}{l}\text { CR-656 } \\
\text { NR37MP0 }\end{array}$ & $09 / 22 / 05$ & 0.07 & 0.94 & 67.15 & 2.24 & 1.05 & 75.25 & 5.37 & 1.05 & 0.56 & 1.61 \\
\hline $\begin{array}{l}\text { CR-656 } \\
\text { NR38MP0 }\end{array}$ & $09 / 27 / 05$ & 0.07 & 0.01 & 0.52 & 0.02 & 0.08 & 5.97 & 0.43 & 0.08 & 0.59 & 0.67 \\
\hline $\begin{array}{l}\text { CR-656 } \\
\text { NR39MP0 }\end{array}$ & $09 / 28 / 05$ & 0.13 & 0.33 & 41.49 & 1.38 & 1.07 & 136.59 & 9.76 & 1.07 & 0.24 & 1.31 \\
\hline $\begin{array}{l}\text { PA-166 } \\
\text { NR40MP0 }\end{array}$ & $09 / 28 / 05$ & 0.25 & 0.35 & 85.24 & 2.84 & 1.04 & 256.21 & 18.30 & 1.04 & 0.34 & 1.38 \\
\hline $\begin{array}{l}\text { Minimum } \\
\text { Reporting } \\
\text { Level }\end{array}$ & & 0.01 & 0.006 & NA & NA & 0.01 & NA & NA & NA & NA & 0.06 \\
\hline Median & & 0.07 & 0.21 & 21.70 & 0.72 & 1.05 & 60.62 & 4.33 & 1.05 & 0.28 & 1.31 \\
\hline
\end{tabular}

All samples were filtered through a 0.45 -micron filter. Values reported as zero indicate concentration less than reporting level shown. Ortho-P Orthophosphate, as phosphorus, $\mathrm{NH} 4-\mathrm{N}$ ammonia, as nitrogen, $\mathrm{NO}_{3}+\mathrm{NO}_{2}-\mathrm{N}$ nitrate plus nitrite, as nitrogen are not shown (concentrations $<0.06 \mathrm{mg} \mathrm{L}^{-1}$ in all samples), $N A$ not applicable

sent to the U.S. Geological Survey National Water Quality Laboratory in Denver, Colorado, for analysis. Laboratory analysis for Ortho- $\mathrm{P}, \mathrm{NH}_{4}-\mathrm{N}$, and $\mathrm{NO}_{3}+\mathrm{NO}_{2}-\mathrm{N}$ were determined using colorimetery or automated segmentedflow spectrophotometry as described in Fishman (1993). Total $\mathrm{N}$ was determined using alkaline persulfate extraction as described in Patton and Kryskalla (2003). Reporting levels for each nutrient analytical method used are given in Table 4. Median concentrations of dissolved $\mathrm{N}$ and dissolved $\mathrm{P}$ were multiplied by areal groundwater fluxes for reaches east and west of New Bern to estimate total groundwater flux to the estuary. Nutrient fluxes for each sampling site were derived using unit groundwater fluxes and concentrations measured at each of the 15 sites (Table 4). Nutrient fluxes in $\mathrm{mg} \mathrm{m}^{-2} \mathrm{~d}^{-1}$ were computed by multiplying unit groundwater flux $\left(\mathrm{m}^{3} \mathrm{~m}^{-2} \mathrm{~d}^{-1}\right)$ times concentration in $\mathrm{mg} \mathrm{L}^{-1}$ times 1,000 (conversion from $\mathrm{m}^{3}$ to $\mathrm{L}$ ). Phosphorus in $\mathrm{mmol} \mathrm{m} \mathrm{m}^{-2} \mathrm{~d}^{-1}$ was computed by dividing flux in $\mathrm{mg} \mathrm{m}^{-2} \mathrm{~d}^{-1}$ by the atomic weight of phosphorus $(30 \mathrm{~g})$. Nitrogen in $\mathrm{mmol} \mathrm{m} \mathrm{m}^{-2} \mathrm{~d}^{-1}$ was computed by dividing total inorganic $\mathrm{N}$ (equivalent to $\left.\mathrm{NH}_{4}-\mathrm{N}\right)$ by the atomic weight of nitrogen $(14 \mathrm{~g})$. 


\section{Results and Discussion}

Annual Groundwater Flux to the Neuse River Estuary Using Seepage Meter Measurements

A major factor that is critical to reasonably estimating annual groundwater flux to an estuary using measured unit fluxes is the width of the groundwater outflow face or discharge zone (the area between the shoreline and offshore; Fig. 3). Fresh groundwater discharging to a saltwater estuary is restricted by heavier saline water that acts as a density barrier, creating an interface between fresh groundwater and saltwater in the estuary and preventing discharge toward the center of the estuary (Fig. 3). Fresh groundwater discharge is restricted to a narrow zone next to the shoreline when the estuary contains more saline water (Fig. 3A). When the estuary contains less saline water, and no or low density differences are present (Fig. 3B), fresh groundwater can discharge in a wider zone to areas further offshore. Based on data from previous investigations, typical discharge zones range from 10 to $1,000 \mathrm{~m}$ wide (Table 2), with decreasing flux offshore (Bokuniewicz (1980); Reay et al. (1992); Staver and Brinsfield (1996). To estimate the discharge area to the NRE, theoretical widths based on the Dupuit-Ghyben-Herzberg model (Fetter 2001), and aquifer and salinity characteristics of the NRE coupled with actual measurements and spatial patterns of groundwater flux made as part of our investigation, were used as discussed below.

Equations derived by Glover (1964) from the DupuitGhyben-Herzberg model of one-dimensional flow in unconfined coastal aquifers (Fetter 2001) also can be used to estimate discharge zone width in the saline part of the aquifer (the part of the aquifer that contains saltwater from the ocean or estuary; Fig. 3). The width of the discharge zone depends on the variables shown in the following equation: (from Fetter 2001)

$X_{0}=-G q^{\prime} / 2 K$

where

$X_{0}$ the distance of the freshwater-saltwater interface from the shoreline;

$G \quad \rho_{\mathrm{w}} /\left(\rho_{\mathrm{s}}-\rho_{\mathrm{w}}\right)$, and $\rho_{\mathrm{w}}$ is the density of freshwater and $\rho_{\mathrm{s}}$ is the density of saline water; $q^{\prime} \quad$ discharge from the aquifer at the coastline per unit length of shoreline $\left(\mathrm{L}^{3} \mathrm{~T}^{-1}\right) \mathrm{L}^{-1}$ (Fetter 2001); and $K$ hydraulic conductivity of the aquifer in $\mathrm{L} \mathrm{T}^{-1}$.

The variables in Eq. 1 must be known or estimated to calculate an estimate of the width of the discharge zone. Before the discharge per unit of shoreline length $\left(q^{\prime}\right)$ can be computed, the dimensions of the aquifer (length and width) must be known to apply the Dupuit-Ghyben-Herzberg model. The first variable, $q^{\prime}$, was computed by approximating the average width of the aquifer along the shoreline and assuming that $20 \%$ of the average annual precipitation for the Coastal Plain estimated by Wilder et al. (1978) recharges the shallow aquifer. The total precipitation recorded at New Bern for 2004 and 2005 during this investigation was 1.24 and $1.35 \mathrm{~m}$ (Southeast Regional Climate Center 2006), with a mean of $1.29 \mathrm{~m}$, which resulted in aquifer recharge of about $0.26 \mathrm{~m}$. The estimated width of the aquifer was obtained by dividing the total land area by the total length of shoreline:

$W_{\mathrm{a}}=\mathrm{WS}_{\text {area }} / S$,

where

$W_{\mathrm{a}} \quad$ average width (m) of aquifer along the shoreline (distance from groundwater divide to shoreline);

$\mathrm{WS}_{\text {area }}$ total area of NRE watershed (area inside hydrologic unit boundary, Fig. 2) minus the estuary water-surface area (dark-shaded areas, Fig. 2) in $\mathrm{m}^{2}=1.42 \times 10^{9}$; and

$S \quad$ total shoreline length $(\mathrm{m})=8.384 \times 10^{5}$.

The variable $G$ in Eq. 1 is the ratio of freshwater density to the difference between saltwater density and freshwater density (Fetter 2001). The most saline water is in the lower part of the NRE at the mouth nearest Pamlico Sound (Fig. 1), where the salinity can be as high as 22 parts per thousand (ppt; Harned and Davenport 1990; Luettich et al. 2000). The estimated mean salinity is about $10 \mathrm{ppt}$ (density = $1.0046 \mathrm{~g} \mathrm{~cm}^{-3}$ ). Water temperature during the investigation ranged from $18.2^{\circ} \mathrm{C}$ during April 2004 to $30.7^{\circ} \mathrm{C}$ during June 2004 (Table 3). Thus, using Eq. 1 and the density of water at $25^{\circ} \mathrm{C}$ with mean salinity of $10 \mathrm{ppt}$, mean $K$ of $10 \mathrm{~m}$ $\mathrm{d}^{-1}$ for the surficial aquifer, and annual discharge along the shoreline of $1.21 \mathrm{~m}^{3} \mathrm{~d}^{-1} \mathrm{~m}^{-1}$, the discharge zone width $\left(X_{0}\right)$ in the area east and downstream from New Bern is

$$
\begin{aligned}
X_{0} & =-G q^{\prime} / 2 K \\
& =-\left(0.9972 \mathrm{~g} \mathrm{~cm}^{-3} /\left(1.0046 \mathrm{~g} \mathrm{~cm}^{-3}-0.9972 \mathrm{~g} \mathrm{~cm}^{-3}\right) * 1.21 \mathrm{~m}^{3} \mathrm{~d}^{-1} \mathrm{~m}^{-1}\right) /\left(2^{*} 10 \mathrm{~m} \mathrm{~d}^{-1}\right) \\
& =-\left(135^{*} 1.21 \mathrm{~m}^{3} \mathrm{~d}^{-1} \mathrm{~m}^{-1}\right) /\left(20 \mathrm{~m} \mathrm{~d}^{-1}\right) \\
& =-8.16 \mathrm{~m} \text { (or about }-10 \mathrm{~m} \text { as a general approximation in the middle to lower NRE })
\end{aligned}
$$


Eq. 1 is less helpful in determining the width of the discharge zone in the freshwater part of the NRE west and upstream from New Bern, however. In this part of the estuary, where average salinity is $0.5 \mathrm{ppt}$ or less, the width of the discharge zone could theoretically be $150 \mathrm{~m}$ or more, a value larger than previously reported in most studies of estuaries. This result is demonstrated by applying Eq. 1 and assuming the salinity of the estuary is $0.5 \mathrm{ppt}$ (density $=$ $0.9974)$ at $25^{\circ} \mathrm{C}$ with $K=20 \mathrm{~m} \mathrm{~d}^{-1}$ and a discharge of $1.21 \mathrm{~m}^{3} \mathrm{~d}^{-1} \mathrm{~m}^{-1}$ :

$$
\begin{aligned}
X_{0} & =-G q^{\prime} / 2 K \\
& =-\left(0.9972 \mathrm{~g} \mathrm{~cm}^{-3} /\left(0.9974 \mathrm{~g} \mathrm{~cm}^{-3}-0.9972 \mathrm{~g} \mathrm{~cm}^{-3}\right) * 1.21 \mathrm{~m}^{3} \mathrm{~d}^{-1} \mathrm{~m}^{-1}\right) /\left(2 * 20 \mathrm{~m} \mathrm{~d}^{-1}\right) \\
& =-\left(4,986 * 1.21 \mathrm{~m}^{2} \mathrm{~d}^{-1}\right) /\left(2 * 20 \mathrm{~m} \mathrm{~d}^{-1}\right) \\
& =-151 \mathrm{~m}
\end{aligned}
$$

Thus, depending on relative densities of freshwater and saltwater at particular locations and times in the estuary, the width of the discharge zone may vary, and decreases as the estuarine water becomes more saline.

Although the width of the discharge zone in the middle and lower estuary is constrained by relatively high salinity, the width of the discharge zone in the freshwater part is not, and therefore is more dependent on the hydraulic characteristics of the aquifer and the recharge to the aquifer. Previous estuary studies did not appear to include freshwater parts of the estuaries, and discharge zones generally were reported to be $50 \mathrm{~m}$ or less (Table 2), with the exception of the carbonate aquifer system in Florida studied by Halley et al. (2005). Reay et al. (1992) reported the widest zone in Cherrystone Inlet in the Chesapeake Bay estuarine system, where discharge decreased with increasing distance from shore (up to $50 \mathrm{~m}$ ). Even though the discharge zone theoretically could be wider, much of the upper NRE channel is only about $300-400 \mathrm{~m}$ wide; thus, the possible maximum width for the discharge zone is approximately 150-200 $\mathrm{m}$ (assuming the estuary receives groundwater discharge from both banks, which leaves about half the total channel width for the discharge zone).
Measurements made during this investigation were used to estimate the discharge zone width in the estuary by evaluating the measured unit groundwater flux with distance from the shoreline. Data collected during this study (Fig. 5; Table 3) indicate that most groundwater flux occurred within $20 \mathrm{~m}$ of the shoreline, and the highest fluxes were generally within $10 \mathrm{~m}$ of the shore, particularly east of New Bern. Measured fluxes were more uniform with distance from shore west of New Bern (NR35-37; Fig. 5) with $0.04 \mathrm{~m}^{3} \mathrm{~m}^{-2} \mathrm{~d}^{-1}$ being the lowest non-zero flux recorded in this reach (Table 2). At three transects measured west of New Bern, fluxes appeared to be somewhat higher and generally more uniform between the shoreline and 10 $\mathrm{m}$, with no apparent decrease with distance from the shore (Fig. 5; Table 3). Water depth was too great to place seepage meters beyond $10 \mathrm{~m}$ at these three transects, so measurements could not confirm whether any decrease in flux with increasing distance from shore occurred in this reach. Unit groundwater fluxes measured using seepage meters in the NRE ranged from nearly zero to $0.43 \mathrm{~m}^{3} \mathrm{~m}^{-2}$ $\mathrm{d}^{-1}$, with a median flux for the NRE of $0.07 \mathrm{~m}^{3} \mathrm{~m}^{-2} \mathrm{~d}^{-1}$ and a mean flux of $0.10 \mathrm{~m}^{3} \mathrm{~m}^{-2} \mathrm{~d}^{-1}$ (Table 3; Fig. 2). These measurements generally fall within the range of previous
Fig. 5 Relation between unit groundwater flux and distance from shore from measurements made during three periods (April and June 2004, and September 2005) in the Neuse River estuary. Triangles indicate measurements made west of New Bern

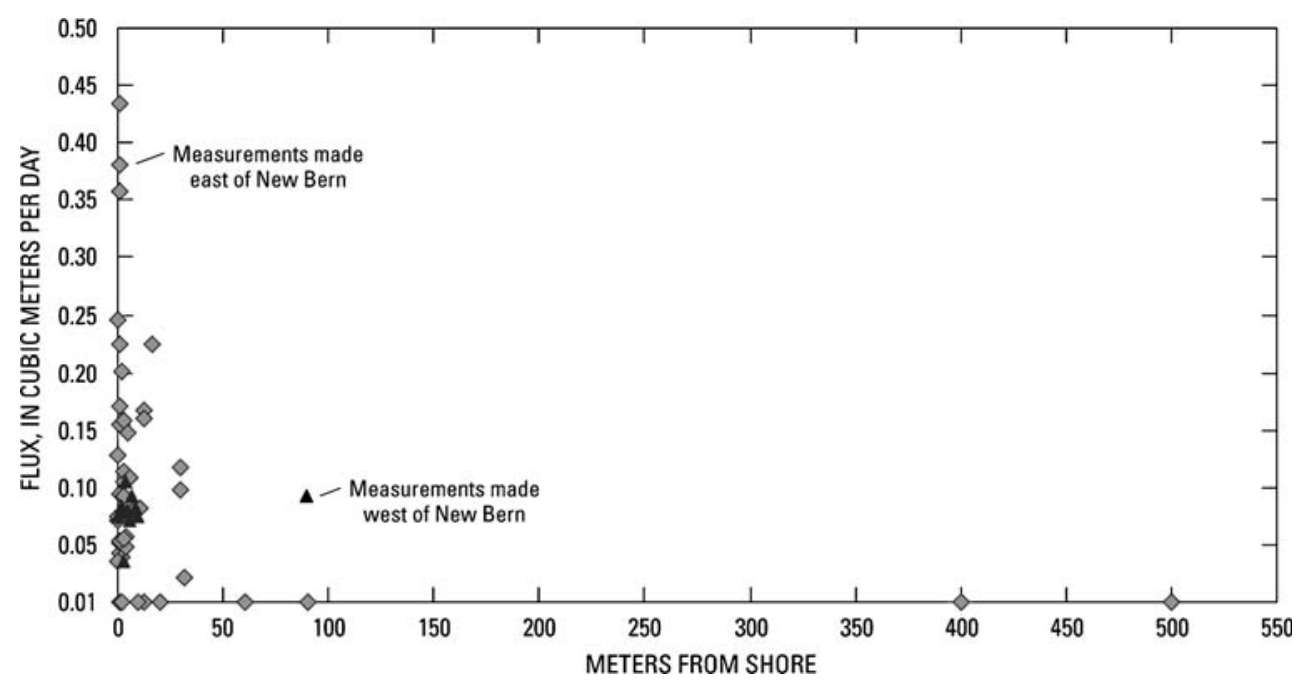


groundwater flux measurements reported for other estuaries along the east coast of the United States (Table 2). Groundwater fluxes in the NRE were similar both east and west of New Bern (medians of 0.07 and $0.08 \mathrm{~m}^{3} \mathrm{~m}^{-2}$ $\mathrm{d}^{-1}$, respectively), indicating that groundwater discharge from the bed of the estuary within the discharge zone could be considered to be somewhat uniform.

Groundwater flux to the NRE was computed by using a constant width of $10 \mathrm{~m}$ east of New Bern, three estimated discharge-zone widths west of New Bern, and a typical discharge of $0.09 \mathrm{~m}^{3} \mathrm{~m}^{-2} \mathrm{~d}^{-1}$ (a value between the mean and median given in Table 3) for both reaches. The similar groundwater fluxes derived from measurements imply similar hydrogeologic and lithologic characteristics of the NRE, both upstream (west) and downstream (east) from New Bern. However, based on available hydrogeologic information (Floyd 1969; Winner and Coble 1996), the two reaches are different, and these differences are addressed when applying Darcy's Law in the next section. This apparent discrepancy suggests that more hydrogeologic study may be necessary in the upstream section of the NRE. Three discharge-zone widths were assumed (Table 5): (1) a minimum discharge-zone width of $20 \mathrm{~m}$; (2) an estimate of $50 \mathrm{~m}$, the limit past which most other researchers did not find detectable seepage in estuarine environments; and (3) $160 \mathrm{~m}$, the approximate maximum width calculated using the Dupuit-Ghyben-Herzberg model (Fetter 2001) that would be possible in much of the upper NRE, as discussed above. Thus, three different scenarios with increasing widths $(20,50$, and $160 \mathrm{~m}$; Table 5) were used to provide groundwater discharge estimates for this reach, to evaluate which estimated seepage rates of the three appeared to best agree with groundwater discharge estimates established by other methods or with data reported in the literature. The total annual groundwater discharge to the entire estuary during 2004-2005, with an average rainfall of $1.29 \mathrm{~m}$, is estimated to range between $2.86 \times 10^{8} \mathrm{~m}^{3}$ or $9.07 \mathrm{~m}^{3} \mathrm{~s}^{-1}$ and $4.33 \times 10^{8} \mathrm{~m}^{3}$ or $13.73 \mathrm{~m}^{3} \mathrm{~s}^{-1}$ (Table 5).

The width of the discharge zone between New Bern and the mouth of the estuary was assumed to be approximately $10 \mathrm{~m}$ because the computed zone is limited by generally high salinity $(>10 \mathrm{ppt})$, thus restricting the zone to $10 \mathrm{~m}$ or less. In general, most measurable unit groundwater fluxes occurred within $10 \mathrm{~m}$ of shore in this reach (based on fluxes shown in Table 3; Fig. 5); thus, $10 \mathrm{~m}$ seems to be a reasonable approximation for the middle and lower parts of the NRE. Also, in this part of the NRE, discharge of groundwater throughout the middle of the estuary was assumed to be near zero based on previous research, indicating no significant groundwater discharge over most of the central portion of the estuary (Luettich et al. 2000) and on marine resistivity surveys conducted in parallel with this study (Fig. 6). From these surveys (Cross et al. 2006), fresh (high resistivity) groundwater discharge areas are restricted to areas parallel to the shoreline downstream from New Bern. Most fresh water is contained in the confined Yorktown aquifer beneath the NRE bed, as indicated in the marine resistivity profile (Fig. 6) and in several other profiles shown in Cross et al. (2006). Measured fluxes that occurred near a buried paleochannel near Cherry Point, North Carolina (Daniel et al. 1996; Wrege and Jen 2004), were typical of fluxes observed at other sites sampled in the NRE. Highest observed unit groundwater fluxes $\left(>0.1 \mathrm{~m}^{3}\right.$ $\mathrm{m}^{-2} \mathrm{~d}^{-1}$ ) were measured in the area between New Bern and Minnesott Beach (Fig. 2). This approach assumes that all groundwater discharge originates (is recharged) within the NRE basin and that the principal aquifer discharging groundwater to the NRE (the surficial aquifer) is unconfined. Water from underlying or confined systems, if there is a breach in the confining unit, for example, could contribute water that is not accounted for in this analysis.

Annual Groundwater Flux Using a Standard Conceptual Water Budget and Darcy's Law

The groundwater flux estimates derived from our measurements also were compared with estimates derived by using a standard conceptual water budget for the Coastal Plain and general aquifer characteristics using Darcy's Law. A water budget method using $0.26 \mathrm{~m}$ of recharge to the surficial aquifer (about $20 \%$ of the average rainfall based on information in Wilder et al. 1978) was applied to the land area $\left(1.42 \times 10^{9} \mathrm{~m}^{2}\right.$; Fig. 2$)$ of the watershed surrounding the NRE to estimate annual groundwater flow to the NRE $(3.69 \times$ $10^{8} \mathrm{~m}^{3}$; Table 5) equal to a daily flux of about $12 \mathrm{~m}^{3} \mathrm{~s}^{-1}$.

Darcy's Law (Eq. 3) was also used to estimate groundwater discharge using typical aquifer characteristics for the area:

$\mathrm{Q}=\mathrm{KIA}$,

where:

$Q$ discharge, in $\mathrm{m}^{3}$;

$K$ hydraulic conductivity of the aquifer, in $\mathrm{m} \mathrm{d}^{-1}$;

$I$ change in hydraulic head over distance, in $\mathrm{m} / \mathrm{m}$ (dimensionless), based on average gradient obtained from previous studies (Giese et al. 1992; Eimers et al. 1994); and

$A$ area of the aquifer face discharging to the estuary, in $\mathrm{m}^{2}$, based on average length and thickness of the aquifer adjacent to the estuary.

Basic conceptual information for the hydrogeology of the NRE was provided by Floyd (1969), Giese et al. (1992), Eimers et al. (1994), and Winner and Coble (1996). A hydraulic conductivity of $10 \mathrm{~m} \mathrm{~d}^{-1}$ (the median for the entire Coastal Plain in Winner and Coble (1996)), and an estimated 


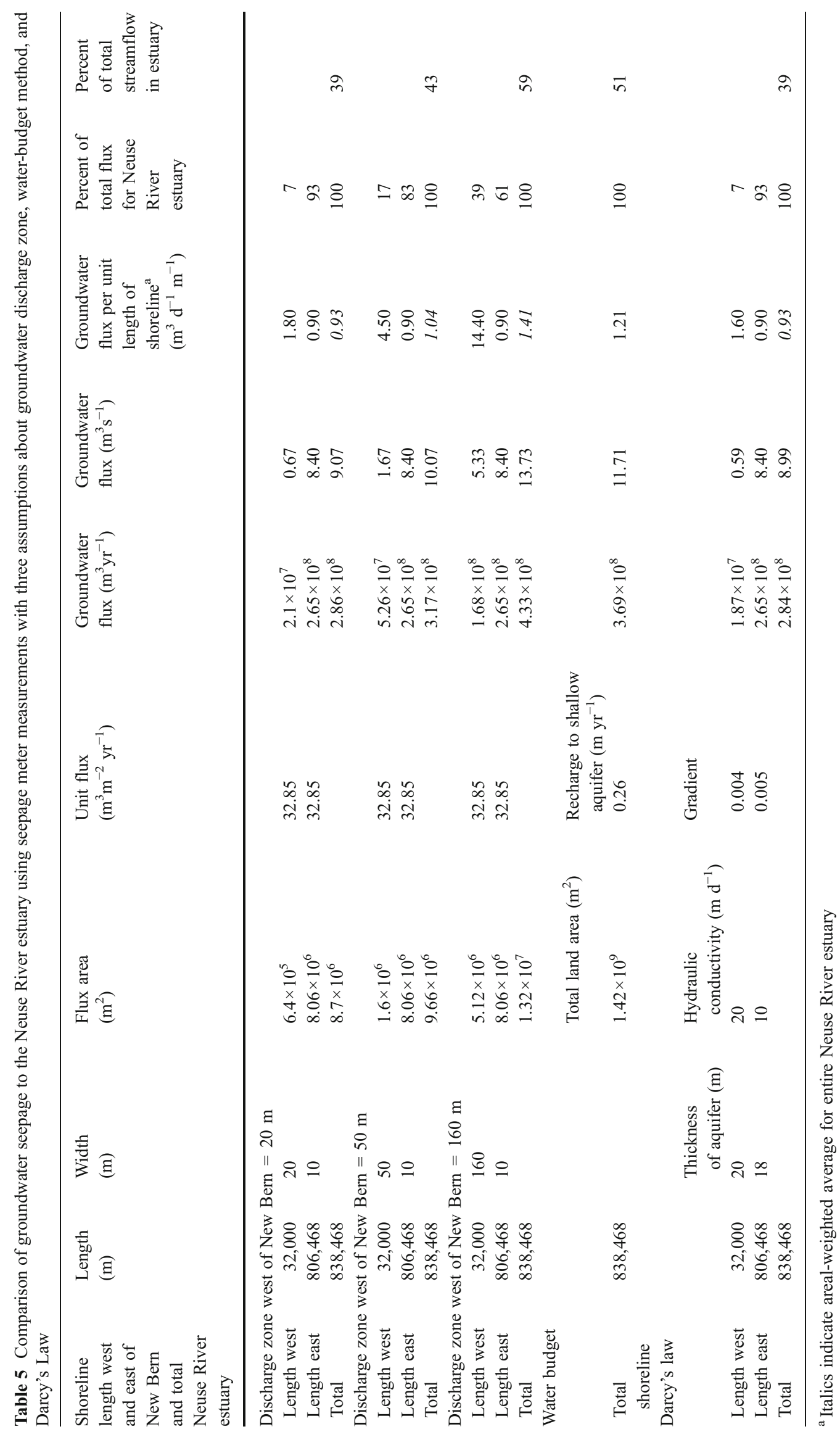




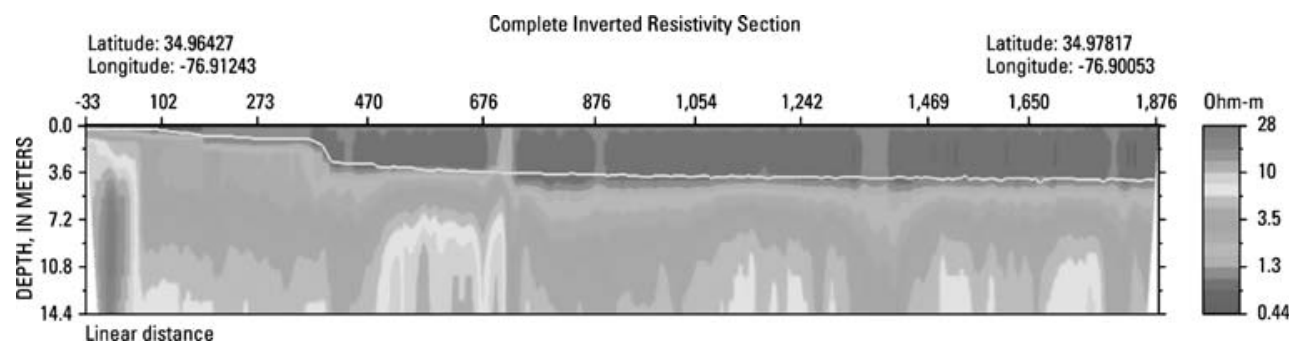

Fig. 6 A representative continuous resistivity profile from beneath the Neuse River estuary bed collected perpendicular to the shore near Slocum Creek (Fig. 2). Dark shades beneath sediment-water interface at left of diagram indicate the presence of fresh groundwater (high electrical resistivity). Shoreline is to the left; all distances are in meters; white line indicates sediment-water interface average aquifer thickness of $18 \mathrm{~m}$ (based on the midpoint of 10-21 m range in thickness at Cherry Point reported by Eimers et al. (1994) and assuming some thickening of deposits eastward (Giese et al. (1992)), where no well data are available), were assumed for the surficial aquifer east of New Bern. The average gradient for the surficial aquifer was derived from Giese et al. (1992) and was estimated to be about $8 \mathrm{~m} / 1,500 \mathrm{~m}$ or 0.005 (Table 5). For the area west of New Bern, $20 \mathrm{~m} \mathrm{~d}^{-1}$ was used as the average hydraulic conductivity for the combined surficial and Castle Hayne aquifer estimated from the average hydraulic conductivity given by Winner and Coble (1996) for the Castle Hayne aquifer. The thickness of the upper weathered portion of the Castle Hayne west of New Bern was estimated to be $20 \mathrm{~m}$ (Floyd 1969). For our analysis, the surficial aquifer was assumed to be in direct contact with the Castle Hayne aquifer and also to behave as an unconfined aquifer in this reach. We assumed that the average gradient for the combined surficial and Castle Hayne aquifer was influenced by surficial aquifer characteristics and was slightly lower (0.004; Table 5) due to a lower gradient in the Castle Hayne aquifer (estimated as 0.002 from information published in Giese et al. 1992). Application of Darcy's Law using average hydraulic characteristics of aquifers in both reaches of the NRE (Table 5) yielded an estimate of $2.84 \times 10^{8} \mathrm{~m}^{3} \mathrm{yr}^{-1}$ or about $9 \mathrm{~m}^{3}$ $\mathrm{s}^{-1}$ for the entire NRE.

\section{Annual Nutrient Fluxes}

Concentrations of nitrogen, which occurred primarily as ammonium in samples collected from the minipiezometers that were screened between 0.3 and $1.2 \mathrm{~m}$ beneath the bed of the estuary, ranged from 0.04 to $14.5 \mathrm{mg} \mathrm{L}^{-1}$, with a median concentration of $1.05 \mathrm{mg} \mathrm{L}^{-1}$ (Table 4). Using the median nitrogen concentration as the best estimate of groundwater concentration, and assuming a $10-\mathrm{m}$ discharge zone between New Bern and the mouth of the estuary and a 20-m discharge zone between New Bern and Streets Ferry (Table 5) as the best approximation of annual flux to the NRE (as explained in the following section), we estimated the median flux of nitrogen to the estuary to be about 333 tonnes $\mathrm{yr}^{-1}$. This is equal to about $4 \%$ of the annual nitrogen flux from all sources and about $8 \%$ of upstream surfacewater nitrogen flux to the estuary for a typical year (Table 6). Concentrations of dissolved phosphorus, primarily from orthophosphate, ranged from 0.01 to $4.22 \mathrm{mg} \mathrm{L}^{-1}$, with a median of $0.21 \mathrm{mg} \mathrm{L}^{-1}$ (Table 4). The median flux to the estuary, using the same assumption as above, was about 66 tonnes of phosphorus $\mathrm{yr}^{-1}$ or about $17 \%$ of that delivered by surface-water inflow and about $5 \%$ of all sources of phosphorus to the estuary (Table 6). The largest nitrogen fluxes estimated for this study ( $>18 \mathrm{mmol} \mathrm{m} \mathrm{m}^{-2} \mathrm{~d}^{-1}$; Table 4) occurred in areas along the north bank near Minnesott Beach, and on both the north and south banks between New Bern and near Broad Creek (Fig. 2; Table 4). The highest estimated phosphorus fluxes $\left(>0.5 \mathrm{mmol} \mathrm{m}^{-2} \mathrm{~d}^{-1}\right)$ occurred in groundwater collected along the north bank from NR4 near Minnesott Beach, and from the upper portion of the NRE near Streets Ferry (Fig. 2; Table 4).

Importance of Groundwater Discharge in the Neuse River Estuary

The importance of groundwater and its role in the functioning of an estuary, particularly as it relates to primary productivity, has not been extensively studied. Over the last 30 years, however, interest has increased in determining the importance of groundwater in estuarine systems. Reference has been made to Luettich et al. (2000) regarding their conclusion that groundwater was an insignificant source of nutrients to the NRE. Buzzelli and Christian (2001), estimated that groundwater contributed about $5 \%$ of freshwater inflow of the NRE, also implying that the contribution of groundwater was small with respect to nutrients. Neither of these studies included the shoreline area of the estuary where groundwater discharge is most likely. The purpose of our study was to provide several documented methods to derive groundwater flux estimates to the NRE and, subsequently, using basic water-quality concentration data, to provide estimates of nutrient flux from groundwater. The following discussion assesses the validity of our groundwater and nutrient flux estimates and, 
Table 6 Estimated nitrogen and phosphorus fluxes to the Neuse River estuary from major sources, excluding oceanic exchange, for an average precipitation year $(1.27 \mathrm{~m})$

\begin{tabular}{|c|c|c|c|c|}
\hline Source & $\begin{array}{l}\text { Annual tonnes } \\
\text { of nitrogen }{ }^{\mathrm{a}-\mathrm{e}}\end{array}$ & $\begin{array}{l}\text { Percent } \\
\text { of total }\end{array}$ & $\begin{array}{l}\text { Annual tonnes } \\
\text { of phosphorus }{ }^{f-j}\end{array}$ & $\begin{array}{l}\text { Percent } \\
\text { of total }\end{array}$ \\
\hline Bottom-sediment flux & $3,711^{\mathrm{a}}$ & 41 & $845^{\mathrm{f}}$ & 64 \\
\hline Groundwater flux & $333^{\mathrm{b}}$ & 4 & $66^{\mathrm{g}}$ & 5 \\
\hline Surface-water flux from upstream of NRE & $4,354^{\mathrm{c}}$ & 49 & $385^{\mathrm{h}}$ & 29 \\
\hline Precipitation flux to NRE & $400^{\mathrm{d}}$ & 4 & $0^{\mathrm{i}}$ & 0 \\
\hline Surface-water flux from adjacent coastal tributaries & $177^{\mathrm{e}}$ & 2 & $18^{\mathrm{j}}$ & 1 \\
\hline 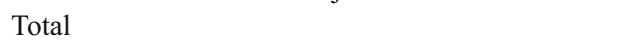 & 8,975 & 100 & 1,314 & 100 \\
\hline
\end{tabular}

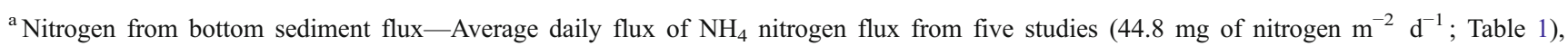
assuming regeneration from half the area of the estuary. Source: Luettich et al. (2000).

${ }^{\mathrm{b}}$ Daily flux of $94.5 \mathrm{mg} \mathrm{m}^{-2} \mathrm{~d}^{-1}$ applied to area of groundwater discharge $\left(9.66 \times 10^{6} \mathrm{~m}^{2}\right)$; Table 1 . Source: This paper.

${ }^{\mathrm{c}}$ Average total nitrogen load in surface water upstream from NRE for year having average rainfall. Source: North Carolina Department of Environment and Natural Resources (2001); Spruill et al. (2005).

${ }^{\mathrm{d}}$ Dissolved nitrogen (from nitrate and ammonium) in rainfall falling on surface area of NRE $\left(4.55 \times 10^{8} \mathrm{~m}^{2}\right)$. Source: $\sim 1 \mathrm{mg} \mathrm{L}{ }^{-1} \mathrm{DIN}$ (from National Atmospheric Deposition Program/National Trends Network 1997).

${ }^{\mathrm{e}}$ Nitrogen flux computed by multiplying average total dissolved nitrogen concentration by $0.125 \mathrm{~m}$ of runoff (equal to 5 in. of surface runoff

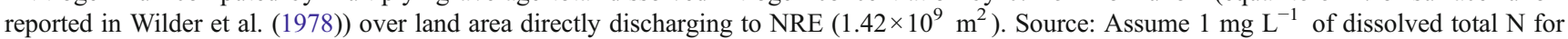
Coastal Plain tributary streams based on average for Coastal Plain streams (Spruill et al. 1998).

${ }^{\mathrm{f}}$ Phosphorus from bottom sediment flux-Average daily flux of orthophosphate-phosphorus $\left(10.2 \mathrm{mg} \mathrm{m}^{-2} \mathrm{~d}^{-1}\right.$, assuming regeneration from half the area of the estuary $\left(4.55 \times 10 \mathrm{~m}^{2}\right)$. Source: Fisher et al. (1982).

${ }^{\mathrm{g}}$ Daily flux of $18.9 \mathrm{mg} \mathrm{m}^{-2} \mathrm{~d}^{-1}$ applied to area of groundwater discharge $\left(9.66 \times 10^{6} \mathrm{~m}^{2}\right)$; Table 1 . Source: This paper.

${ }^{\mathrm{h}}$ Average total phosphorus load from surface water upstream from NRE for year having average rainfall. Source: Spruill et al. (2005).

${ }^{\mathrm{i}}$ Source: Assumed insignificant.

${ }^{\mathrm{j}}$ Phosphorus flux computed by multiplying average total dissolved phosphorus concentration by $0.125 \mathrm{~m}$ of runoff (equal to 5 in. of surface runoff reported in Wilder et al. 1978) over land area directly discharging to NRE $\left(1.42 \times 10^{9} \mathrm{~m}^{2}\right)$. Source: Assume $0.1 \mathrm{mg} \mathrm{L}^{-1}$ of dissolved total P for Coastal Plain tributary streams based on average for Coastal Plain streams (Spruill et al. 1998).

ultimately, the importance of groundwater in affecting primary productivity and ecology of the NRE.

The question, then, is how reasonable are our estimates of groundwater flux to the NRE? Our measurements of groundwater discharge agree fairly well with gross estimates of discharge derived from both Darcy's Law and general knowledge of hydrology in the Coastal Plain of North Carolina. Groundwater seepage measurements, coupled with model estimates of discharge zone width, produced groundwater discharge estimates in the NRE that ranged from 7 to $11 \%$ of the annual average freshwater riverine inflow to the estuary $\left[3.9 \times 10^{9} \mathrm{~m}^{3}\right.$ (Robbins and Bales 1995; Buzzelli and Christian 2001)].

How does the use of seepage meters, which were not prefilled with water, affect the estimates? Shaw and Prepas (1989) found that the use of empty bags deployed for times of less than $45 \mathrm{~min}$, as was done for some locations in our study, can produce elevated flux values compared to bags which are prefilled with $1 \mathrm{~L}$ of water. On the other hand, Belanger and Montgomery (1992) found in tank experiments that seepage meter rates, derived from using $1 \mathrm{~L}$ prefilled bags, were about $77 \%$ of the actual seepage and $57 \%$ of the calculated rate based on interstitial composition of tank sediments, and thus yielded seepage rates lower than actual seepage measured in the experimental tanks. These results show that both methods can bias seepage rates, one positively and one negatively, suggesting that the use of unfilled bags for short time periods of deployment may not severely overestimate seepage rates. The median and mean seepage rates $\left(0.07\right.$ and $\left.0.1 \mathrm{~m}^{3} \mathrm{~m}^{-2} \mathrm{~d}^{-1}\right)$ of all measurements made during our study of the NRE (Table 3) represent seepage within about $10-50 \mathrm{~m}$ of the shoreline and were within the range of seepage rates reported for other studies shown in Table 2. Although the variability of groundwater flux in the NRE is large $\left(<0.01-0.43 \mathrm{~m}^{3} \mathrm{~m}^{-2} \mathrm{~d}^{-1}\right)$, it is similar to variability observed in other estuaries shown in Table 2 and indicates that more detailed mapping of discharge zones in the NRE is warranted for more precise flux estimation at local scales.

Probably one of the best practical ways to assess the validity of the estimates presented in this paper is to compare whether the amount of groundwater discharged to the estuary agrees with a typical ratio of groundwater to total streamflow, which is commonly expressed as a base-flow index (BFI) - the BFI reported for streams in the Coastal Plain ranges from $40 \%$ to more than $70 \%$ (Harned and Davenport 1990; McMahon and Lloyd 1995). The total discharge from the Neuse River to Pamlico Sound has been estimated to be $4.73 \times 10^{9} \mathrm{~m}^{3}$ (Giese et al. 1985; Kim 1990) for an average year. Inflow to the NRE during years having average precipitation (about $1.27 \mathrm{~m}$ ) has been estimated to be $3.9 \times$ $10^{9} \mathrm{~m}^{3}$ (Robbins and Bales 1995). The difference in 
streamflows between upstream and downstream is about $7.3 \times 10^{8} \mathrm{~m}^{3}$ and is, therefore, the approximate gain in flow between Streets Ferry and the mouth of the NRE during an average year. Based on these estimates, the base flow or groundwater contribution derived from measurements made for this study (and Darcy's Law and the water budget method) is between $2.86 \times 10^{8}$ and $4.33 \times 10^{8} \mathrm{~m}^{3}$ annually. This produces a BFI between about $40 \%$ and $60 \%$ of the surface-water inflow to the NRE between Streets Ferry and the mouth, which is in agreement with previously reported BFI for coastal streams in the Albemarle-Pamlico drainage basin. Estimates which were much below $40 \%$ would imply lower actual recharge, or losses to either evapotranspiration or leakage to confined aquifers that far exceed rates that are currently considered reasonable. Estimates greater than $70 \%$ would suggest an additional source, such as significant discharge from a confined aquifer or from an aquifer where the hydraulic characteristics were estimated incorrectly.

Our groundwater flux estimates also can be evaluated by comparing them with estimates derived using radon tracer measurements. Using radon data from a parallel study (J. Crusius, U.S. Geological Survey, written communication, June 15, 2006), the estimated groundwater contribution to the area west of New Bern was $1.9 \mathrm{~m}^{3} \mathrm{~d}^{-1} \mathrm{~m}^{-1}$ of shoreline, somewhat higher than the $1.21 \mathrm{~m}^{3} \mathrm{~d}^{-1} \mathrm{~m}^{-1}$ calculated for the entire estuary using a recharge of $0.26 \mathrm{~m} \mathrm{yr}^{-1}$, as shown in Table 5 for the water budget method. This estimate indicates that the discharge could be higher in the $16-\mathrm{km}$ reach west of New Bern than in the reach to the east, possibly reflecting a difference in hydrogeology or some other factor. Based on available information, however, the estimate derived from measurements using a $20-\mathrm{m}$ discharge zone width best agrees with estimates using radon (3-9 $\mathrm{m}^{3} \mathrm{~s}^{-1}$ reported by J. Crusius (written communication, June 15,2006$)$ and estimates generated by using Darcy's Law (about $9 \mathrm{~m}^{3} \mathrm{~s}^{-1}$; Table 5) - an annual groundwater flux of $2.86 \times 10^{8} \mathrm{~m}^{3}$ appears to be the most reasonable estimate based on our analysis. The estimated flux to the NRE of nearly $12 \mathrm{~m}^{3} \mathrm{~s}^{-1}$, using the water budget method, is higher than the estimated flux using radon or Darcy's Law and suggests that the recharge to the surficial aquifer $\left(0.26 \mathrm{~m} \mathrm{yr}^{-1}\right)$ could be somewhat high for this part of the Coastal Plain. However, recent work by Coes et al. (2007) indicated that annual recharge rates measured using hydrograph separation in four areas of the Coastal Plain in 2004 ranged from 0.15 to $0.34 \mathrm{~m}$, with three of the four sites yielding values of $0.28 \mathrm{~m}$ or greater, providing further evidence that the recharge rate of $0.27 \mathrm{~m}$ is reasonable. Evapotranspiration or subsurface leakage may be somewhat greater than rates estimated by Wilder et al. (1978).

With respect to the importance of nutrients, groundwater flux appears to contribute less than $6 \%$ of both nitrogen and phosphorus from all sources directly to the estuary (Table 6).
The estimated groundwater inflow, however, provides about $8 \%$ of the nitrogen and $17 \%$ of the phosphorus transported in surface water from upstream areas of the NRE. As indicated previously, the major potential source of nitrogen $(7,000$ tonnes) in the NRE is sediment (Luettich et al. 2000). Even though large quantities of nutrients are available to the water column from sediment, some question remains as to the availability of these nutrients to phytoplankton in the upper $0.6 \mathrm{~m}$ of the estuarine water column where most primary production occurs. Although the relative contribution of nutrients in groundwater appears minor in relation to the quantity potentially available from sediment, nutrients in groundwater could be important because they are released into the water column through advection, compared to simple molecular diffusion from the bed. This is particularly true when advective forces overcome the density gradients that may occur during summer stratification. This phenomenon can be seen in thermal infrared photographs of the Nauset Marsh near Eastham, Massachusetts, and published in Portnoy et al. (1998), in which cold low-salinity groundwater plumes can be seen moving into the warm estuarine water away from the shoreline toward the center of the estuary. Diffusing nutrients from bottom sediments typically are trapped by density gradients and confined to the denser saline bottom waters, where typically lower primary production takes place during summertime stratified periods (Luettich et al. 2000) or after periodic rainfall events (Cloern 1991).

Even though the mass of nutrients derived from groundwater seems relatively small-only $4 \%$ to $5 \%$ of the total nutrient pool at the scale of the entire NREgroundwater in some localized areas in the NRE can have high fluxes and concentrations (Fig. 2), which could affect the distribution of biota- both micro- and macro-fauna and flora. Although the median groundwater concentration of total inorganic nitrogen was $1.05 \mathrm{mg} \mathrm{L}^{-1}$ (derived almost entirely from ammonium), much higher concentrations and fluxes of ammonium were measured at some sites $(7.6 \mathrm{mg}$ $\mathrm{L}^{-1}$ and $23 \mathrm{mmol} \mathrm{m}^{-2} \mathrm{~d}^{-1}$ at NR4 and $1.27 \mathrm{mg} \mathrm{L}^{-1}$ and nearly $40 \mathrm{mmol} \mathrm{m}^{-2} \mathrm{~d}^{-1}$ at NR34, Table 4; Fig. 2), which could affect primary production at times and places in the estuary where primary production is otherwise nitrogen limited. It also may be important that groundwater provides about $8 \%$ of the nitrogen and almost $17 \%$ of the phosphorus surface-water load from upstream areas, which is forced through advection into the upper part of the water column where nutrients are available to primary producers, even under conditions when the estuary normally is stratified, particularly during the summer months.

It should be noted that our nutrient flux estimates to the NRE were based on groundwater collected from the piezometers and not from the seepage meters. Because of sediment-water interface reactions that can take place before groundwater discharges into the estuary, nutrient 
concentrations in groundwater collected from piezometers may be different from concentrations collected from seepage meters. Further research focused on this possibility would be beneficial in providing more definitive groundwater flux estimates.

Although the groundwater flux estimates from our study appear generally reasonable, more accurate and precise estimates of groundwater discharge in the NRE will require additional study. Some researchers (Reay et al. 1992; Staver and Brinsfield 1996) found decreasing head or discharge with distance from shoreline. Decreasing discharge with increasing distance from shore was observed in our study, although a quantifiable relation between head and discharge was not, partly because of the difficulty in making accurate head measurements in the NRE, which frequently is windy and turbulent. Another reason for our inability to discern a correlation between discharge rate and head, or between either of these variables and the distance from shore, could be the highly heterogeneous bed-sediment material and locally variable hydraulic properties in the NRE. Variable hydraulic conductivity of the bed could obscure such relations, and more detailed work defining hydraulic properties will be necessary to determine if the expected relations are discernible in this system. Effects of tidal variations on discharge need to be evaluated, which would require continuous discharge and head monitoring. The lack of reach-specific hydrogeology data, particularly in the area west of New Bern, is another limitation on determining groundwater discharge to the estuary. Additional measurements downstream from Cherry Point to the mouth of the NRE also are needed to verify our estimates, particularly because estimates of groundwater discharge in this study were assumed to represent downstream areas that were not sampled.

There are some notable differences related to findings from our study compared to findings from studies in other areas along the east coast of the United States. Nitrate was not detected $\left(<0.06 \mathrm{mg} \mathrm{L}^{-1}\right.$; Table 4$)$ in any of the samples collected during this study, even though high nitrate concentrations $\left(>10 \mathrm{mg} \mathrm{L}^{-1}\right)$ were detected in studies conducted in the Chesapeake Bay (Staver and Brinsfield 1996) and Massachusetts (Portnoy et al. 1998) in the nearshore areas, with decreasing concentrations offshore. This result also was found at other sites in the Chesapeake Bay by Speiran (1996), where water having oxygen and oxidized forms of nitrogen can move through clean sands with little nitrate-reducing effect of riparian buffers. Based on previous work in the Albemarle-Pamlico drainage basin, the surficial aquifer, which is composed largely of fine-tomedium-grained sands and provides groundwater to Coastal Plain streams and estuaries, including the NRE, contains water with substantial amounts of dissolved organic carbon, characteristic of groundwater in the North Carolina Coastal
Plain (Spruill et al. 1998; Tesoriero et al. 2004). Shallow groundwater in this area does not have the high nitrate concentrations found in many other coastal areas of the east coast of the United States-low or absent nitrate in groundwater from this area occurs because of generally reducing conditions, which are prerequisite for denitrification. Consequently, the primary form of biologically available nitrogen in groundwater discharging to the NRE is ammonium, which may be used by phytoplankton (Paerl et al. 1995). High concentrations of ammonium were observed by Paerl et al. (1995) in the Neuse River at New Bern, which could be due to discharging groundwater. Results from our study support the assessment of Paerl et al. (1995), as measurements made on the northeast bank just downstream from New Bern (NR34; Fig. 2) resulted in a flux of almost $40 \mathrm{mmol} \mathrm{m}^{-2} \mathrm{~d}^{-1}$ of ammonium (Table 4). High concentrations of ammonium $\left(>0.2 \mathrm{mg} \mathrm{L}^{-1}\right)$ have been observed in discharging groundwater in other areas of the Coastal Plain in the Albemarle-Pamlico drainage basin (Spruill et al. 1998). It is interesting that the piezometer at site NR34 is located adjacent to an extensive wetland that is not apparently affected by human activities along the northeast bank. Although no nitrogen was detected as nitrate in groundwater samples collected during this study, it is possible that nitrogen as nitrate could occur locally in groundwater in clean sands extending into the estuary next to nitrogen source areas (for example, cultivated fields), but that such conditions were not encountered in the relatively limited sampling effort for this study. Additional water samples from piezometers placed along transects perpendicular to the shoreline at various locations in the estuary, particularly in areas where agricultural activity occurs, or residential or urban land is present and is known to be a likely source of nitrate, could be collected and evaluated to determine if nitrate occurs in groundwater discharging to the NRE. Nevertheless, nitrogen occurring either as ammonium or nitrate can fuel primary productivity in a nitrogen-limited estuarine system. Similarly, locally high concentrations and fluxes of phosphorus in groundwater also could fuel primary productivity in areas of the NRE that are often phosphorus limited, such as the upper part of the estuary (Paerl et al. 2004). Some of the highest phosphorus fluxes occurred in this area (Fig. 2).

\section{Implications for Future Studies}

Groundwater nutrient contribution to coastal environments has been generally considered small relative to surface water (Buddemeier 1996). Most of the 179 estuarine water and nutrient budgets included in the Land-Ocean Interactions in the Coastal Zone (LOICZ) project, part of the International Biosphere-Geosphere Program, an international program to evaluate earth systems in response to 
global environmental change (Smith et al. 2003), included groundwater as a minor or negligible component of the coastal nutrient and water budgets (LOICZ Modelling Node at http://nest.su.se/MNODE/). Although several LOICZ budgets did include groundwater sources (including that for the NRE prepared by Buzzelli and Christian 2001), many considered the groundwater contribution to be zero because of the unavailability of data. Without explicit measurements of groundwater discharge to estuaries, however, a significant source of nutrient inflow may be overlooked. With a groundwater discharge of $0.93 \mathrm{~m}^{3} \mathrm{~d}^{-1}$ $\mathrm{m}^{-1}$ of shoreline found in the NRE (Table 5), groundwater contributes overall about $4 \%$ to $5 \%$ of the nitrogen and phosphorus to the estuary. In a study of groundwater flux at five different sites around the world (Burnett et al. 2006), groundwater discharge rates were measured at some sites that exceeded $20 \mathrm{~m}^{3} \mathrm{~d}^{-1} \mathrm{~m}^{-1}$ of shoreline, and averaged more than $2 \mathrm{~m}^{3} \mathrm{~d}^{-1} \mathrm{~m}^{-1}$ at a site in Australia and from 0.23 to more than $20 \mathrm{~m}^{3} \mathrm{~d}^{-1} \mathrm{~m}^{-1}$ at a site in New York (United States). This demonstrates an even greater potential to deliver a larger percentage of nutrients to estuaries in these areas, and the necessity to quantify groundwater inputs.

The occurrence of spatially varied fluxes in the NRE (Fig. 2) demonstrates that it is the distribution of fluxes in a coastal environment that is extremely important in quantifying groundwater and associated nutrient inflow to an estuary, and in making reasonable comparisons of nutrient budgets between estuaries. Our study shows, based on quantitative information showing largest groundwater fluxes occurring nearshore and generally decreasing offshore (Fig. 5), that to accurately estimate groundwater flux into estuaries like the NRE, seepage meter sampling must be concentrated within $10-20 \mathrm{~m}$ of the shoreline where most discharge occurs, or calculated total estuarine fluxes will be biased low. To further substantiate total estuarine groundwater fluxes derived from seepage meter field measurements, estimates from other methodologies, as recommended in Burnett et al. (2006) and as was done for our study of the NRE, are advisable.

Groundwater and associated nutrient fluxes are measurable in the NRE, although similar to conclusions from previous work, groundwater appears to be a minor source of nutrients to the NRE relative to watershed and benthic inputs. Nevertheless, possible effects of large, locally derived inputs of nitrogen or phosphorus in groundwater on primary productivity and biotic distribution in the NRE deserve further research. As pointed out by Johannes (1980), even though submarine groundwater discharge (SGD) may be generally much smaller than surface-water discharge, SGD may still be of great ecological significance. Groundwater discharges have been linked to the occurrence of nuisance algal blooms including brown tide in Long Island (Laroche et al. 1997) and red tide in Korea (Lee and Kim 2007). Stimulation of aquatic plant growth by inorganic nitrogen in submarine groundwater discharges has also been reported by Maier and Pregnall (1990) and LaPointe (1997). Table 1 shows large unit inputs of nitrogen and phosphorus in groundwater discharges to the NRE compared to inputs of these elements through benthic release into the water column. Fluxes of both nitrogen and phosphorus in groundwater are almost twice those from benthic sources. This observation is particularly relevant in controlling mass loads into an estuary for mitigation of various phenomena considered to be problems. Areas that may have harmful algal blooms or fish kills could be controlled by localized conditions, including nutrient fluxes from discharging groundwater, and not necessarily by overall loading to the system from upstream sources, as is assumed for total maximum daily load (TMDL) programs to control and improve water quality.

Acknowledgments The authors appreciate funding support from the U.S. Geological Survey for this work. The authors thank A. Gerald Strickland, Douglas G. Smith, Erik L. Staub, and Eric M. Sadorf of the U.S. Geological Survey, North Carolina Water Science Center in Raleigh, for their help with data-collection activities, and the many reviewers who improved the manuscript substantially through their comments and observations.

\section{References}

Bear, J. 1979. Hydraulics of groundwater. New York: McGraw-Hill International Book Co.

Belanger, T.V., and M.T. Montgomery. 1992. Seepage meter errors. Limnology and Oceanography 37: 1787-1795.

Bokuniewicz, H. 1980. Groundwater seepage into Great South Bay, NewYork. Estuarine and Coastal Marine Science 10: 437-444.

Bowen, J.D., and J. Hieronymus. 2000. Neuse River estuary modeling and monitoring project stage 1-Predictions and uncertainty analysis of response to nutrient loading using a mechanistic eutrophication model. Water Resources Research Institute of The University of North Carolina, Report 325-D.

Bratton, J.F., J.K. Böhlke, F.T. Manheim, and D.E. Krantz. 2004. Ground water beneath coastal bays of the Delmarva PeninsulaAges and nutrients. Ground Water 42: 1021-1034.

Buddemeier, R. W. (ed.). 1996. Groundwater Discharge in Coastal Zone: Proceedings of an International Symposium. LOICZ Reports and Studies No. 8, LOICZ, Texel, The Netherlands.

Burkholder, J.M. 2001. History of toxic Pfiesteria in North Carolina estuaries from 1991 to the present. Bioscience 51: 827-841.

Burkholder, J.M., D.A. Dickey, C.A. Kinder, R.A. Reed, M.A. Mallin, M. R. McIver, L.B. Cahoon, G. Melia, C. Brownie, J. Smith, N. Deamer, J. Springer, H.B. Glasgow, and D. Toms. 2006. Comprehensive trend analysis of nutrients and related variables in a large eutrophic estuary-A decadal study of anthropogenic and climatic influences. Limnology and Oceanography 51: 463-487.

Burnett, W.C., P.K. Aggarwal, A. Aureli, H. Bokuniewicz, J.E. Cable, M.E. Charette, E. Kontar, S. Krupa, K.M. Kulkarni, A. Loveless, W.S. Moore, J.A. Oberdorfer, J. Oliveira, N. Ozyurt, P. Povinec, A.M.G. Privitera, R. Rajar, R.T. Ramessur, J. Scholten, T. Stieglitz, M. Taniguchi, and J.V. Turner. 2006. Quantifying submarine groundwater discharge in the coastal zone via multiple methods. Science of the Total Environment 367: 498-543. 
Buzzelli, C.P., and R.R. Christian. 2001. Dissolved inorganic phosphorus and nitrogen budgets for the Neuse River Estuary, North Carolina, USA using Cabaret. LOICZ-Biogeochemical Modelling Node; accessed May 2006 at http://data.ecology.su.se/ MNODE/North\%20America/NeuseRiver/NeuseRiverbud.htm

Capone, D.G., and M.F. Bautista. 1985. A groundwater source of nitrate in nearshore marine sediments. Nature 313: 214-216.

Cloern, J.E. 1991. Annual variations in river flow and primary production in the South San Francisco Bay Estuary (USA). In Estuaries and coasts - Spatial and temporal intercomparisons, eds. M. Elliot and J. Ducrotoy. ECSA19 Symposium. Olsen and Olsen.

Coes, A.L., T.B. Spruill, and M.J. Thomasson. 2007. Multiple-method estimation of recharge rates at diverse locations in the North Carolina Coastal Plain, USA. Hydrogeology Journal 15: 773-788.

Corbett, D.R., J. Chanton, W. Burnett, K. Dillon, C. Rutkowski, and J. Fourqurean. 1999. Patterns of groundwater discharge into Florida Bay. Limnology and Oceanography 44: 1045-1055.

Cross, V.A., J.F. Bratton, E. Bergeron, J.K. Meunier, J. Crusius, and D. Koopmans. 2006. Continuous resistivity profiling data from the upper Neuse River Estuary, North Carolina, 2004-2005. U.S. Geological Survey Open-File Report 2005-1306.

Crusius, J., K.D. Kroeger, P. Henderson, L. Ryckman, K. Halloran, J. A. Colman, D. Koopmans, J.F. Bratton, and M.A. Charette. 2005. Submarine groundwater discharge to a small estuary estimated from radon and salinity measurements and a box model. Biogeosciences 2: S13-S15.

Daniel, C.C., III, R.D. Miller, and B.M. Wrege. 1996. Application of geophysical methods to the delineation of paleochannels and missing confining units above the Castle Hayne aquifer at U.S. Marine Corps Air Station, Cherry Point, North Carolina. U.S. Geological Survey Water-Resources Investigations Report 954252.

Dodd, R., G. McMahon, and S. Stichter. 1992. Watershed planning in the Albemarle-Pamlico estuarine system Report 1-Annual average nutrient budgets. North Carolina Department of Environment, Health, and Natural Resources Albemarle-Pamlico Estuarine Study Report No. 92-10.

Eimers, J.L., C.C. Daniel, III, and R.W. Coble. 1994. Hydrogeology and simulation of ground-water flow at U.S. Marine Corps Air Station, Cherry Point, North Carolina, 1987-90. U.S. Geological Survey Water-Resources Investigations Report 94-4186.

Fetter, C.W. 2001. Applied Hydrogeology, 4th edition. Upper Saddle River, New Jersey: Prentice Hall.

Fisher, T.R., P.R. Carlson, and R.T. Barber. 1982. Sediment nutrient regeneration in three North Carolina estuaries. Estuarine Coastal and Shelf Science 14: 101-116.

Fishman, M.J. 1993. Methods of analysis by the U.S. Geological Survey National Water Quality Laboratory; determination of inorganic and organic constituents in water and fluvial sediments. U.S. Geological Survey Open-File Report 93-125.

Floyd, E.O. 1969. Ground-water resources of Craven County, North Carolina: U.S. Geological Survey Hydrologic Investigations Atlas HA-343.

Giese, G.L., H.B. Wilder, and G.G. Parker, Jr. 1985. Hydrology of major estuaries and sounds of North Carolina. U.S. Geological Survey Water-Supply Paper 2221.

Giese, G.L., J.L. Eimers, and R.W. Coble. 1992. Simulation of ground-water flow in the Coastal Plain aquifer system of North Carolina: U.S. Geological Survey Professional Paper 1404-M.

Glover, R.E. 1964. The pattern of fresh-water flow in a coastal aquifer. In H.H. Cooper, Jr. (comp.), Sea water in coastal aquifers. U.S. Geological Survey Water-Supply Paper 1613-C:32-35.

Halley, R.W., C.D. Reich, P.W. Swarzenski, and C.D. Langevin. 2005. Multidisciplinary investigations of submarine flow to Biscayne Bay, Florida. EOS Transactions, American Geophysical Union 86 (18), Abstract Number B33D-07.
Harned, D.A., and M.S. Davenport. 1990. Water-quality trends and basin activities and characteristics for the Albemarle-Pamlico estuarine system, North Carolina and Virginia. U.S. Geological Survey Open-File Report 90-398.

Haruthunian, A. 1997. Seasonal and spatial variations in benthic organic nitrogen remineralization in the Neuse River estuary, NC. United States (USA). Ph.D. dissertation. The University of North Carolina, Chapel Hill, North Carolina.

Johannes, R.E. 1980. The ecological significance of submarine discharge of groundwater. Marine Ecology Progress Series 3: 365-373.

Kim, S. 1990. Physical processes and fine-grained sediment dynamics in the Neuse River estuary, North Carolina, United States (USA). Ph.D. dissertation. The University of North Carolina, Chapel Hill, North Carolina.

Krantz, D.E., F.T. Manheim, J.F. Bratton, and D.J. Phelan. 2004. Hydrogeologic setting and ground water flow beneath a section of Indian River Bay, Delaware. Ground water 42: 1035-1051.

LaPointe, B. 1997. Nutrient thresholds for bottom-up control of macroalgal blooms on coral reefs in Jamaica and southeast Florida. Limnology and Oceanography 42: 1119-1131.

Laroche, J., R. Nuzzi, R. Waters, K. Wyman, P.G. Falkowski, and D. W.R. Wallace. 1997. Brown tide blooms in Long Island's coastal waters linked to interannual variability in groundwater flow. Global Change Biology 3: 397-410.

Lee, D.R. 1977. A device for measuring seepage flux in lakes and estuaries. Limnology and Oceanography 22: 140-147.

Lee, Y., and G. Kim. 2007. Linking groundwater-borne nutrients and dinoflagellate red-tide outbreaks in the southern sea of Korea using a Ra tracer. Estuarine, Coastal, and Shelf Science 71: 309-317.

Lloyd, O.B., Jr., and C.C. Daniel, III. 1988. Hydrogeologic setting, water levels, and quality of water from supply wells at the U.S. Marine Corps Air Station, Cherry Point, North Carolina: U.S. Geological Survey Water-Resources Investigations Report 884034.

Luettich, R.A., J.E. McNinch, H. Paerl, C.H. Peterson, J.T. Wells, M. Alperin, C.S. Martens, and J.L. Pinckney. 2000. Neuse River estuary modeling and monitoring project stage $1-$ Hydrography and circulation, water column nutrients and productivity, sedimentary processes and benthic-pelagic coupling, and benthic ecology: Water Resources Research Institute of The University of North Carolina, Report 325-B.

Maier, C., and A.M. Pregnall. 1990. Increased macrophyte nitrate reductase activity as a consequence of groundwater input of nitrate through sandy beaches. Marine Biology 107: 263-271.

Manheim, F.T., D.E. Krantz, and J.F. Bratton. 2004. Studying ground water under Delmarva coastal bays using electrical resistivity. Ground Water 42: 1052-1068.

Matson, E.A., M.M. Brinson, D.D. Cahoon, and G.J. Davis. 1983 Biogeochemistry of the Pamlico and Neuse River estuaries. Water Resources Research Institute of The University of North Carolina, Report 191.

McMahon, G., and O.B. Lloyd, Jr. 1995. Water-quality assessment of the Albemarle-Pamlico drainage basin, North Carolina and Virginia environmental setting and water-quality issues. U.S. Geological Survey Open-File Report 95-136.

McMahon, G., and M.D. Woodside. 1997. Nutrient mass balance for the Albemarle-Pamlico drainage basin, North Carolina and Virginia, 1990. Journal of the American Water Resources Association 33: 573-589.

National Atmospheric Deposition Program/National Trends Network. 1997. NADP/NTN wet deposition in the United States 1996. Illinois State Water Survey.

North Carolina Department of Environment and Natural Resources. 2001. PHASE II of the total maximum daily load for total nitrogen to the Neuse River estuary, North Carolina, Final. North 
Carolina Department of Environment and Natural Resources, Division of Water Quality, Raleigh, North Carolina.

Nowicki, B.L., E. Requintina, D. Van Keuren, and J. Portnoy. 1999. The role of sediment denitrification in reducing ground-waterderived nitrate inputs to Nauset Marsh estuary, Cape Cod, Massachusetts. Estuaries 22: 245-259.

Paerl, H.W. 1983. Factors regulating nuisance blue-green algal bloom potentials in the lower Neuse River, North Carolina. Water Resources Research Institute of the University of North Carolina, Report No. 188.

Paerl, H.W., M.A. Mallin,, J. Rudek, and P.W. Bates. 1990. The potential for eutrophication and nuisance algal blooms in the lower Neuse River estuary. North Carolina Department of Natural Resources and Community Development, AlbemarlePamlico Estuarine Study. Report 90-15.

Paerl, H.W., M.A. Mallin, C.A. Donahue, M. Go, and B.L. Peierls. 1995. Nitrogen loading sources and eutrophication of the Neuse River estuary, North Carolina-Direct and indirect roles of atmospheric deposition. Water Resources Research Institute of The University of North Carolina, Report No. 291.

Paerl, H.W., L.M. Valdes, A.R. Joyner, and M.P. Piehler. 2004. Solving problems resulting from solutions evolution of a dual nutrient management strategy for the eutrophying Neuse River Estuary, North Carolina. Environmental Science and Technology 38: 3068-3073.

Patton, C.J., and J.R. Kryskalla. 2003. Methods of analysis by the U.S. Geological Survey National Water Quality Laboratory-Evaluation of alkaline persulfate digestion as an alternative to Kjeldahl digestion for determination of total and dissolved nitrogen and phosphorus in water. U.S. Geological Survey Water-Resources Investigations Report 03-4174.

Portnoy, J.W., B.L. Nowicki, C.T. Roman, and D.W. Urish. 1998. The discharge of nitrate-contaminated groundwater from developed shoreline to marsh-fringed estuary. Water Resources Research 34: 3095-3104.

Reay, W.G., D.L. Gallagher, and G.M. Simmons, Jr. 1992. Groundwater discharge and its impact on surface water quality in a Chesapeake Bay inlet. Water Resources Bulletin 28: 1121-1134.

Rizzo, W.M., and R.R. Christian. 1996. Significance of subtidal sediments to heterotrophically-mediated oxygen and nutrient dynamics in a temperature estuary. Estuaries 19(2B): 475-487.

Robbins, J.C., and J.D. Bales. 1995. Simulation of hydrodynamics and solute transport in the Neuse River estuary, North Carolina. U. S. Geological Survey Open-File Report 94-0511.

Sauber, J. 1998. Neuse River internal nutrient loading studies-19961997. North Carolina Division of Water Quality Initial Report, Raleigh, North Carolina.

Schwartz, M.C. 2003. Significant groundwater input to a coastal plain estuary-Assessment from excess radon. Estuarine Coastal Shelf Science 56: 31-42.

Shaw, R.D., and E.E. Prepas. 1989. Anomalous, short-term influx of water into seepage meters. Limnology and Oceanography 34: $1343-1351$.
Smith, S.V., D.P. Swaney, L. Talaue-McManus, J.D. Bartley, P.T. Sandhei, C.J. McLaughlin, V.C. Dupra, C.J. Crossland, R.W. Buddemeier, B.A. Maxwell, and F. Wulff. 2003. Humans, hydrology, and the distribution of inorganic nutrient loading to the ocean. BioScience 53: 235-245.

Southeast Regional Climate Center. 2006. Monthly climate summary data for New Bern FAA Airport, North Carolina; accessed March 15, 2006, at http://cirrus.dnr.state.sc.us/cgi-bin/sercc/cliMAIN.pl? nc6108.

Speiran, G.K. 1996. Geohydrology and geochemistry near coastal ground-water-discharge areas of the Eastern Shore, Virginia. U.S. Geological Survey Water-Supply Paper 2479.

Spruill, T.B., D.A. Harned, P.M. Ruhl, J.L. Eimers, G. McMahon, K. E. Smith, D.R. Galeone, and M.D. Woodside. 1998. Water quality in the Albemarle-Pamlico drainage basin, North Carolina and Virginia, 1992-95: U.S. Geological Survey Circular 1157.

Spruill, T.B., A.J. Tesoreiro, H.E. Mew, Jr., K.M. Farrell, S.L. Harden, A.B. Colosimo, and S.R. Kraemer. 2005. Geochemistry and characteristics of nitrogen transport at a confined animal feeding operation in a coastal plain agricultural watershed and implications for nutrient loading in the Neuse River basin, North Carolina, 1999-2002. U.S. Geological Survey Scientific Investigations Report 2004-5283.

Staver, K.W., and R.B. Brinsfield. 1996. Seepage of groundwater nitrate from a riparian agroecosystem into the Wye River Estuary. Estuaries 19: 359-370.

Tedder, S.W., J. Sauber, L. Ausley, and S. Mitchell. 1980. Working paper Neuse River investigation 1979. North Carolina Department of Natural Resources and Community Development. [unpaginated]

Tesoriero, A.J., T.B. Spruill, and J.L. Eimers. 2004. Geochemistry of shallow ground water in coastal plain environments in the southeastern United States-Implications for aquifer susceptibility. Applied Geochemistry 19: 1471-1482.

Wells, J.T. 1989. A scoping study of the distribution, composition, and dynamics of water-column and bottom sediments-AlbemarlePamlico Estuarine System. North Carolina Department of Natural Resources and Community Development, Albemarle-Pamlico Estuarine Study Report No. 89-05.

Wilder, H.B., T.M. Robison, and K.L. Lindskov. 1978. Water resources of northeast North Carolina. U.S. Geological Survey Water-Resources Investigations Report 77-81.

Winner, M.D., Jr. and R.W. Coble. 1996. Hydrogeologic framework of the North Carolina Coastal Plain. U.S. Geological Survey Professional Paper 1404-I.

Winter, T.C., J.W. Labaugh, and D.O. Rosenberry. 1988. The design and use of a hydraulic potentiomanometer for direct measurement of differences in hydraulic head between groundwater and surface water. Limnology and Oceanography 33: 1209-1214.

Wrege, B.M., and P.S. Jen. 2004. Data from stratigraphic test holes drilled at the U.S. Marine Corps Air Station, Cherry Point, North Carolina, 1994-2001, and periodic water levels, 2000-2003. U.S. Geological Survey Open-File Report 2004-1434. 